\title{
Living with the Past in Modern Sudanese Village Traditional Pottery Production in the Ad-Dabba Bend of the Nile
}

\author{
Aneta Cedro, Bogdan Żurawski
}

\begin{abstract}
The article presents the results of ethnographic research aimed at recording household economic behaviours within rural communities in the Ad-Dabba Bend of the Nile. The field research conducted in 2015-2019 provided first-hand insight into patterns of the gendered village's ceramic production. The only currently operating household workshops in the area, located in Jabarūna and Rūmī Bakrī, are both run by women who produce mainly vessels for storing and cooling water and incense burners. Local residents remember many other similar workshops run by both women and men, which operated quite recently. The potteries in Ad-Dabba, representing a bigger and better organised workshop industry, are run by male descendants of immigrants from Nigeria, known in Sudan as Takarna. The pottery making is their only source of income and the range of forms they make is varied.
\end{abstract}

Keywords: Sudan, Middle Nile, traditional pottery making, African ceramics, ethnoarchaeology, Hausa, household archaeology

Aneta Cedro, Institute of Mediterranean and Oriental Cultures, Polish Academy of Sciences, Warsaw; acedro@iksio.pan.pl; (D) 0000-0003-4788-3843

Bogdan Żurawski, Institute of Mediterranean and Oriental Cultures, Polish Academy of Sciences, Warsaw; bzurawski@iksio.pan.pl; (D) 0000-0002-9184-2785

This study is a result of field research carried out in the Southern Dongola Reach as a part of the project which, in its most general terms, aims to determine the extent to which the social space in the medieval Nubian village was organised on similar principles as in modern times. There is plenty of evidence from the sphere of material and spiritual culture suggesting that medieval Christians and modern Muslims shared many principles of social organisation and daily life. Their popular religion, customs and beliefs, commemorative calendar and funerary practice were based on the same fundamental attitudes to the supernatural, although the direct sources of their piety might have been different. The above lends credibility to the usage of ethnological analogy as a research method in reconstructing the daily life of medieval inhabitants of the Middle Nile area. 


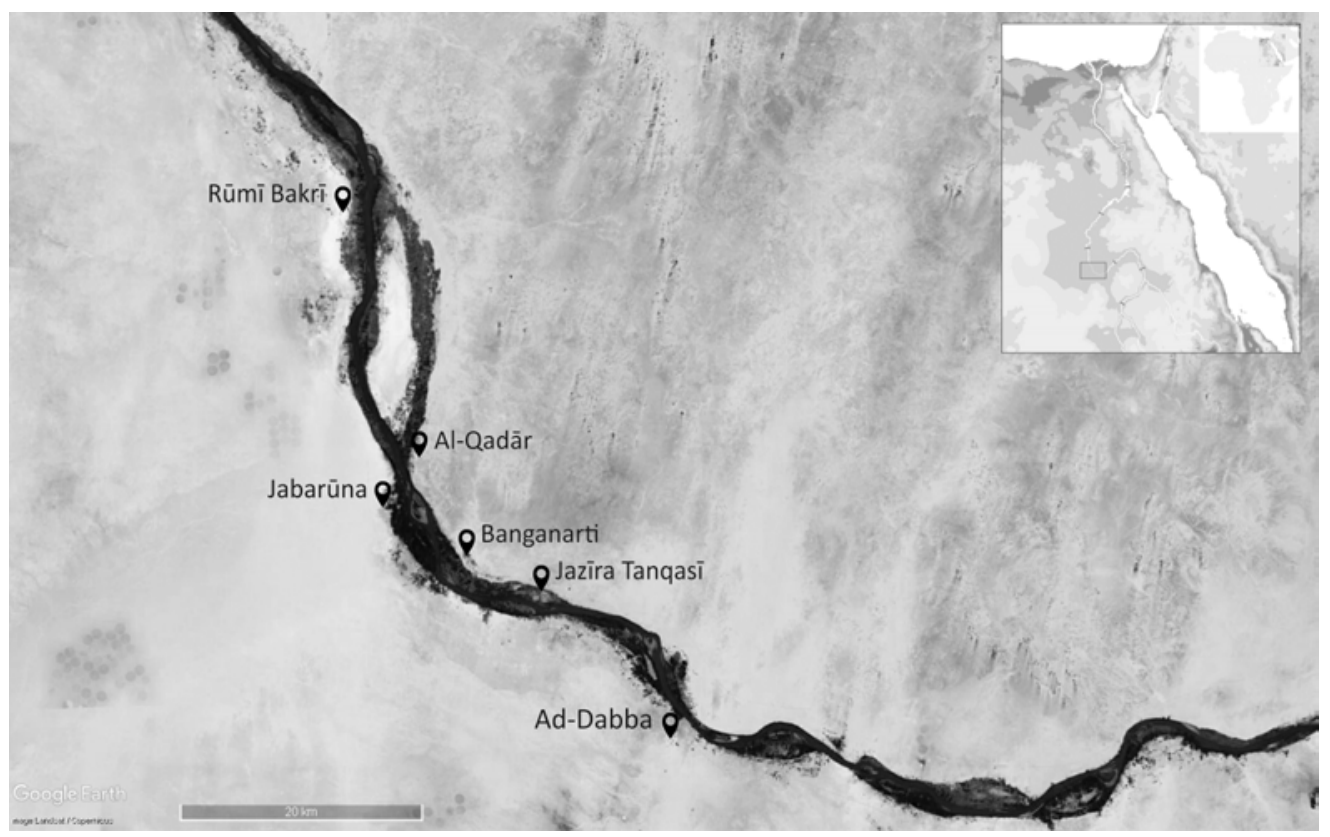

1. Map of the Ad-Dabba Bend area with location of pottery workshops mentioned in the text (source Google Earth; processing: A. Cedro).

Applied with caution, ethnoarchaeological procedures might suggest some guidelines and conceptions on the general principles governing the structure and evolution of the Nubian medieval household. Ethnographic analogies are useful because they can define with more precision the supposed context in which the material objects and household patterns have been created, and what were their functions and purposes in contemporary society. Needless to say, the utmost caution should be used when deducing ancient behaviour or actions associated with object or artefact distribution from their similarity to other objects or contexts that belong to a different time and diverse cultural environment. ${ }^{1}$

This essay is in the main the result of a pilot ethnographic project carried out in Banganarti, Jabarūna, Selib, Rūmī Bakrī and other sites in the so-called Ad-Dabba Bend of the Nile (Fig. 1) with the objective to find out whether ethnographic research among people in the dying professions, such as traditional pottery, makes this feasible at all. Our main concern was the confidence of the female potters, some of whom were elderly women. Such diligence appeared to have been superfluous.

In general, the interviews with craftsmen and craftswomen focused on traditional crafts and subsistence modes. Most time was spent on investigating the issues of pottery making, especially production of large pottery forms. Information was also gathered on carpentry, modes of preparing food, burning charcoal, baking of traditional bread, blacksmithery,

1 See: Balfet 1965: 176-177; Musa Mohammed 1986: 98. 
firing and drying bricks, manufacturing of traditional Sudanese rope beds ('anāqrīb, sing. 'anqarīb), fishing, tannery and leather processing, tailoring, plaiting, weaving ropes and baskets etc. The central issue, however, remained research into the components of the local household as e.g. women's and men's roles in the building and maintaining of houses, kinship terminology, the structured system of social relationships between the villagers, the gendered division of labour and responsibilities linked to maintaining the household.

In the recent past, pottery production in the Southern Dongola Reach, as in most of Sub-Saharan Africa, was dominated by female potters. ${ }^{2}$ Small house-workshops were scattered through the riverine villages where the resources needed for the production, the Nile silt, field leftovers and animal dung, were easily available. Pots were shaped using almost exclusively hand-made techniques. One of the few traces of the bygone ability to use the potter's wheel in Dar Dongola is a photograph from the Sudan Archive that we publish below by kind permission from Durham University (Fig. 2). Among the local potters of Dongola Reach, the memory of using the wheel has today all but vanished. In 1933, John Winter Crowfoot saw 'a primitive wheel' still in use at Nawī near Al-Khandaq. ${ }^{3}$ Further to the north, in the area below the Third Cataract, this tradition is still observed. ${ }^{4}$

The research into traditional pottery production in the Ad-Dabba Bend of the Nile focuses on the left bank workshops in Jabarūna near Al-Ghāba, Rūmī Bakrī, about 40km to the north and in Ad-Dabba, where contrary to the practice observed elsewhere, the pottery production is in the hands of men. The above workshops were visited by a research team several times between 2015 and 2019, as a rule in a good company of a local guide Dafa’Allah ‘Awaụ Muḥammad ‘Alī from Al-Qadār village.

\section{HOUSEHOLD INDUSTRY - JABARŪNA}

The Jabarūna pottery workshops are run by women who live in typical houses in the centre of the village. The pots are prepared inside their houses (Fig. 3) whereas the firing takes place at a site c. $200 \mathrm{~m}$ away, on the outskirts of the village. Some male assistants are employed by them to collect and supply the fuel and to carry the shaped pots to the kiln. The women of Jabarūna produce small quantities of vessels for use by local residents. Pottery making had apparently always been their occupation. Jabarūna had recently become one of the main centres supplying a vast area with earthenware water jars - azyār (sing. zīr).

Four potters from Jabarūna were interviewed, Khadīja 'Abd Allah, Manāl 'Abd as-Sayyīd, Fāṭma 'Abd al-Qādir and Maḥāsin 'Abd Allah. All of them are sisters, daughters

2 See: Arkell 1939: 85, 87; Balfet 1965: 162; Berns 1993: 129-130; Bentley, Crowfoot 1924: 19; Blackman 2000: 135; Bradley 1989: 117; Crowfoot 1925: 133; Gosselain 2008: 1174; Kleppe 1982: 67; MacMichael 1922: 35; Stössel 1984: 66, 136, 137.

${ }^{3}$ Crowfoot 1933: 11.

${ }^{4}$ D'Ercole et al. 2017: 560. 


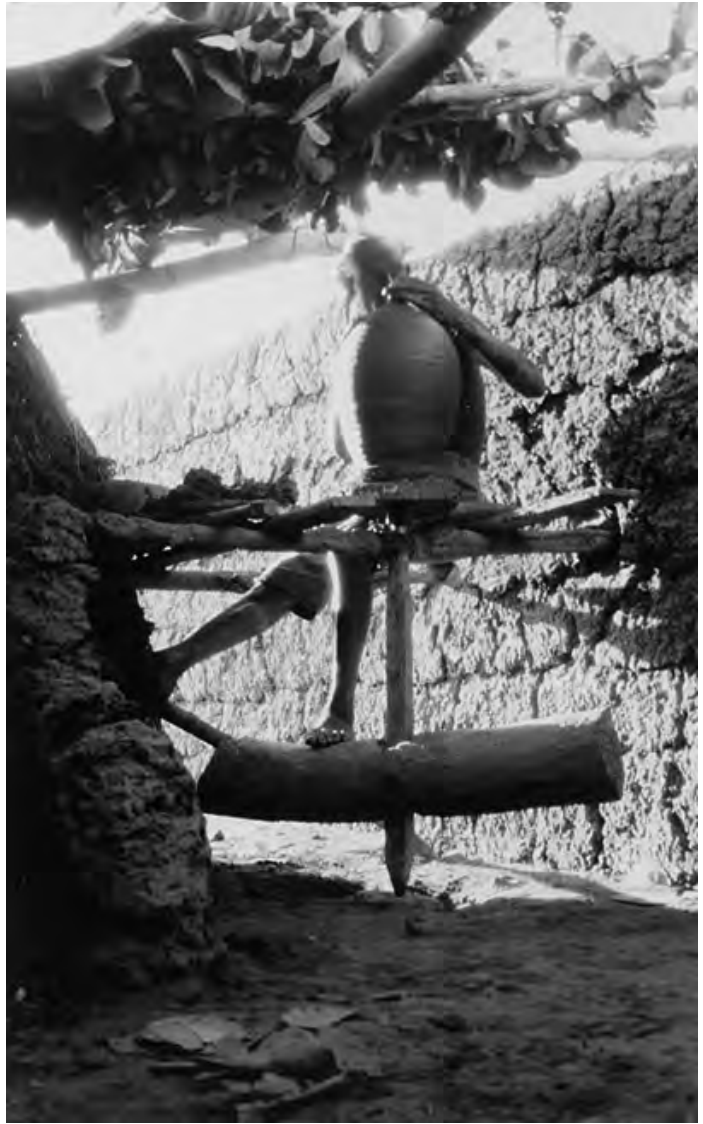

2. Turning a pot on a potter's wheel near Dongola el-Ordi between 1914 and 1926 (Courtesy of the Sudan Library, University of Durham).

of man who was a blacksmith..$^{5}$ They are of Danagla descent and claim to produce the traditional ceramics typical in Dar Dongola. They lived at the beginning in the lower part of Jabarūna called Hiilla Haddādī (haddād = blacksmith), close to the river. After a big flood in 1988, they moved to their present residence. They learned how to make and fire pots from their mother, Hazmalla (Khādim Allah), a potter well known in the researched area. With her sister, Hazmalla continued a long family tradition of pottery making. Her daughters produce mainly traditional big water jars - azyār (see below, Fig. 25), round jars (qulal, sing. qulla), censers (mabākhir, sing. mubkhara) and wide bowls (Nub. kabarūs) for preparing dough or keeping some domestic crops. Sometimes, on demand, they also make other pottery products such as traps for rabbits (see below, Fig. 26), pipes for irrigation (see below, Fig. 27). They obtain raw clay (turāb damīra - damīra = flood season of the Nile)

${ }^{5}$ Marriages between families of potters and blacksmiths were repeatedly recorded in traditional African societies. Both were frequently treated as cast-like subgroups whose representatives were often perceived as impure or being feared by others (see: Gosselain 2008: 1175; Lyons, Freeman 2009; Arkell 1939: 79). 
3. Inside the house-workshop of Jabarūna potters (Phot. R. Łopaciuk).

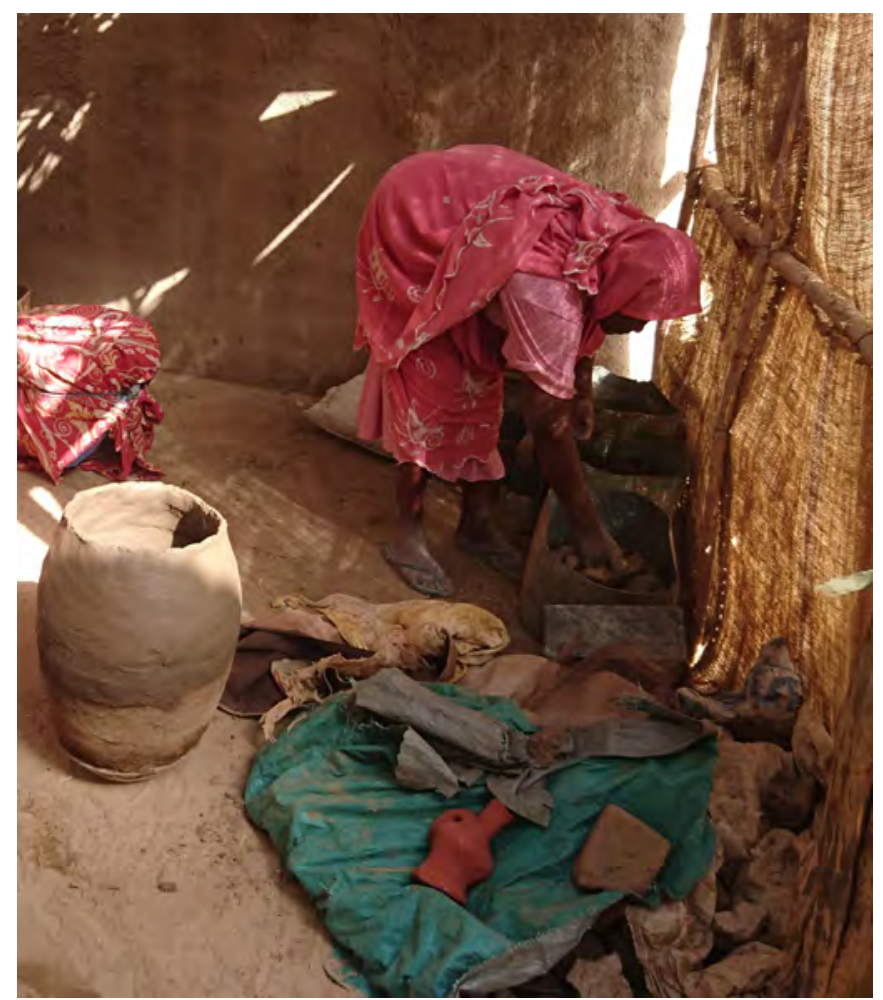

from the banks of the Nile. For the manufacture of vessels, they prepare a paste by mixing alluvial silt with animal manure (from a donkey) and grog - sherds crushed to powder - and add water. According to the information obtained from four above mentioned potters/sisters in 2019, they usually make a large $z \bar{\imath} r$, circa $70 \mathrm{~cm}$ high, within one day only. Its production cycle, however, comprises several stages; first, the bottom part with the rounded base is formed by squashing a lump of clay on the matting, cloth spread on the ground or in a flat, wide metal bowl. After the desired shape (in form of a hemispherical bowl) is achieved and the wall thickness has been unified, the product is left for a short time for drying - in summer the time needed is very short. In the following stages of forming, the central part of the vessel is built by applying roll-shaped lumps of clay, which are thinned down and elongated by hand. When the walls reach the desired height, the surface is scraped and smoothed using a rounded spatula (today usually made from fragments of metal or plastic containers). Finally, the topmost part and the rim are made in a similar way. Each step of forming is made after a short interval for drying.

Finished pots are left to final dry (Fig. 4) for a week under the sun. Before firing, the upper part of the vessel is lubricated with cooking oil, to which a yellow or red powder pigment is added. This powder is purchased in the market and its composition is unknown to the women. In the final step, the outer surface of the upper part of the pot is burnished 


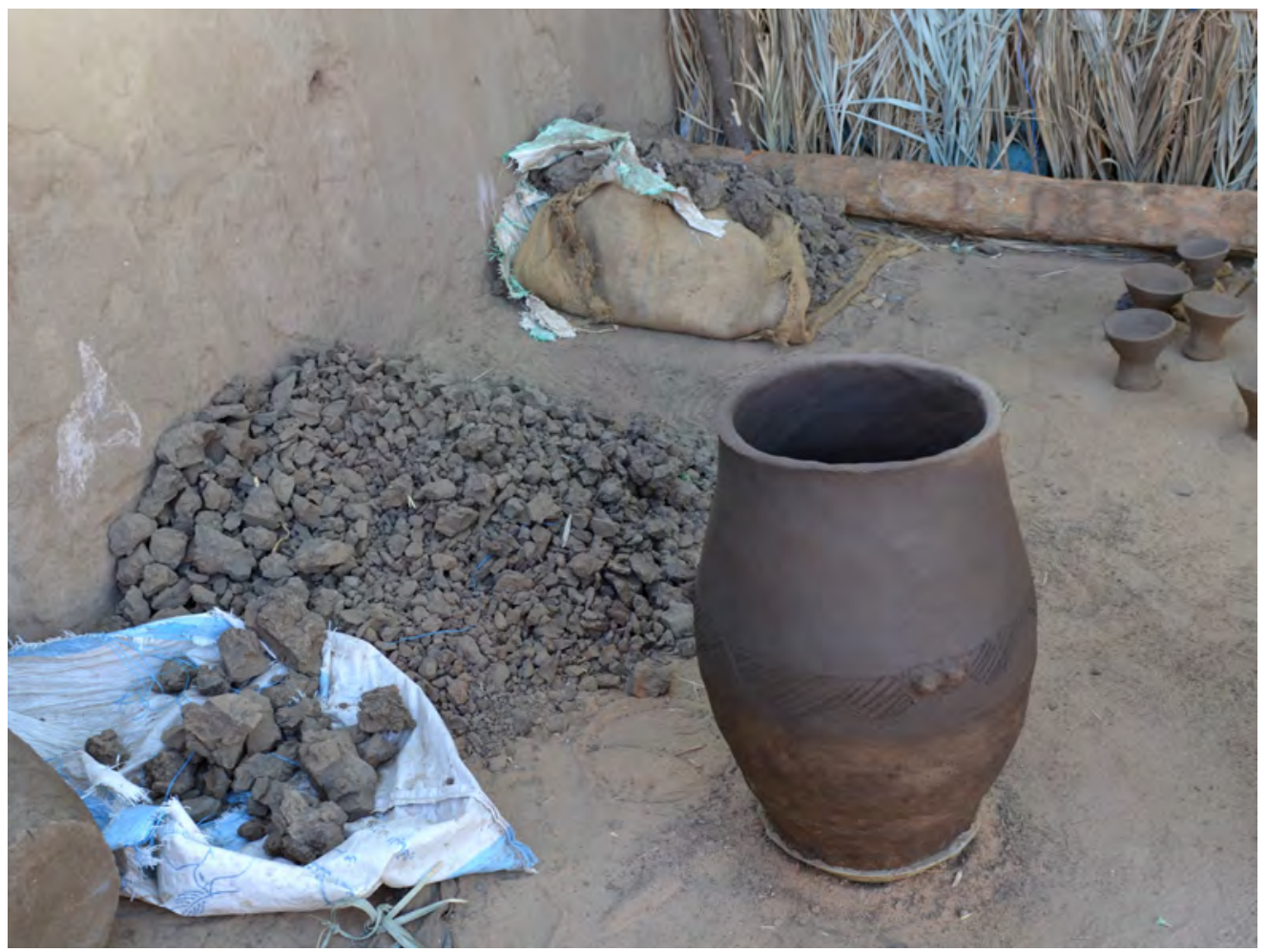

4. Finished zīr left for drying next to the stack of raw Nile clay (Phot. B. Żurawski).

with a pebble. After firing, the vessel takes on a lustrous red or orange colour. Usually, below the burnished zone incised decoration is executed.

The firing place is a shallow, flat depression in the ground. ${ }^{6}$ In Jabarūna, two pits visited were roughly $30-40 \mathrm{~cm}$ in depth and $250 \times 220 \mathrm{~cm}$ and $280 \times 320 \mathrm{~cm}$ in diameter.

The firing process is fuelled by the dung of domestic animals, mostly cattle, sheep and goats. From what the women of Jabarūna say it can be estimated that for firing ten azyār, eight bags ${ }^{7}$ of the animal dung are needed. The amount of fuel depends on the kind of manure. Cattle excreta burn quicker and, therefore, a bigger volume of it is needed. In principle each time only one kind of manure is used for firing but, if necessary, different dung types can be mixed.

The firing starts with spreading a layer of animal manure several centimetres thick at the bottom of the depression. The vessels are laid directly on this layer. The kilns formed in such a way are usually tightly covered with pieces of sheet metal and sherds (Fig. 5). On top, another layer of manure is put down. The kiln is most often ignited from the side.

\footnotetext{
${ }^{6}$ Gosselain 2008: Fig. 6.

${ }^{7}$ The size of $50 \mathrm{~kg}$ cement bag.
} 


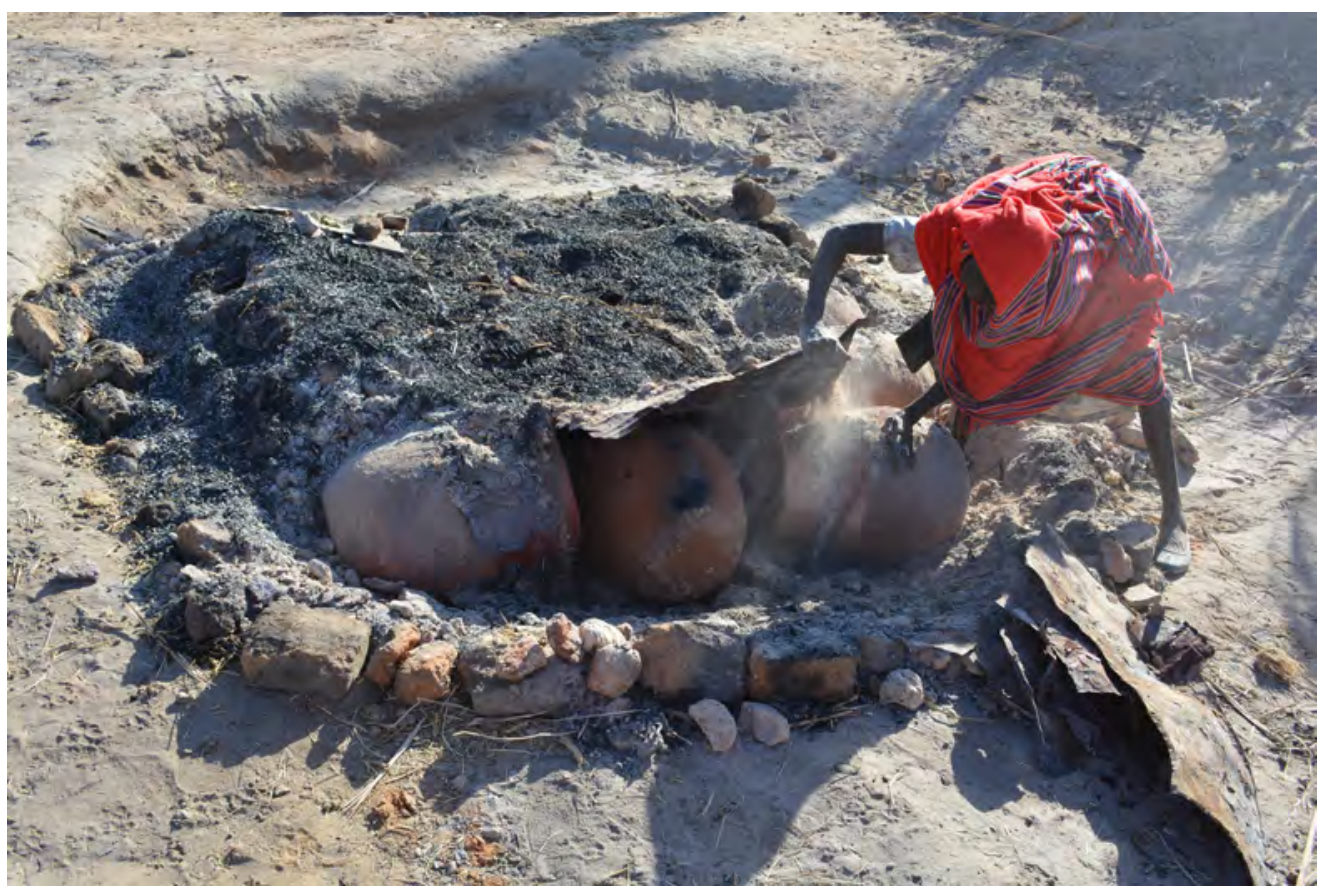

5. Firing jars in a depression; vessels are laid horizontally and covered with metal sheets (Phot. B. Żurawski).

The firing process (of about 30 vessels) takes one day. In one load vessels of different sizes and forms are fired. During the firing that was made on the day of our first visit to Jabarūna, azyār and mabākhir were fired together (Fig. 6). By the last visit, which was aimed at collecting the ordered sāqiya pots (qawādīs, sing. qāâus), in the kiln beside the ordered twenty qawādīs were also about twenty big azyār, some censers and other small fancy pottery products. Cooling of the kiln takes one day. After the whole firing process is accomplished the water jars are smeared inside with a paste prepared by mixing the clay with grog and adding a small quantity of sugar.

The quality of the products is astonishingly high, the azyār are thinly walled and very hard and when knocked they make a clear metallic sound. Very old wares from Jabarūna are still in use among the inhabitants of different villages. 'Abd Allah Aḥmad 'Ummāra, a tailor from Hammūr has several azyār made in Jabarūna. One of them, bought in 1972 still serves for storing drinking water. Another one, bought in 1985, he uses in the summer time. All were brought from Jabarūna by boat. Considerably older ceramic products from Jabarūna - two azyār manufactured in the 1930s and a vessel called in Nubian kantūš (also dahlūb or hummāra) serving in the preparation of dough, and according to the owner's testimony 130 years old, were also encountered. These objects were found in Bakibūl, in the now uninhabited house once belonging to the grandfather of 'Abd al-Qādir 'Abd ar-Raḥmān Dirār, a male nurse in the local hospital, who was the source of this account. 


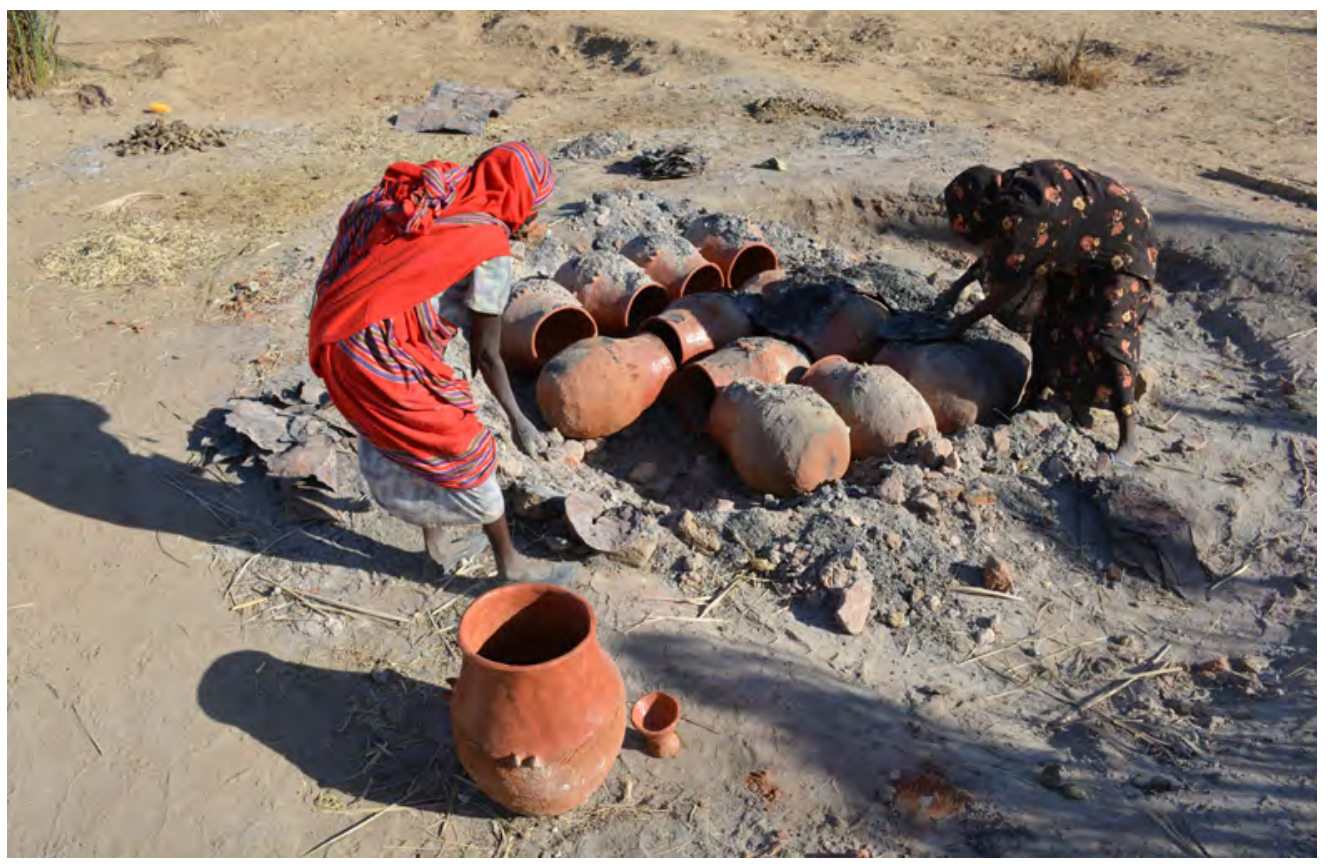

6. Removing jars from the firing place (Phot. B. Żurawski).

\section{HOUSEHOLD INDUSTRY - RŪMĪ BAKRĪ}

In the village of Rūmī Bakrī in the visited house of a farmer, As-Sayyid Marjān, the tradition of making pottery goes back a long way. Family members claim it started as early as the beginning of the nineteenth century, with production passed from generation to generation up to the present day. Their first workshop was situated close to the river and after the flood of 1988, they moved to their present residence. The whole process of production is performed by the wife of the house owner. The family is of Arab origin from the Bidīina Dahmašiyya tribe. There are three families firing pottery products in the village. Their production, however, is seasonal and on a small scale.

The basic ingredient of the ceramic paste is raw alluvial clay (turāb damīra), brought from the river bank. A clump of raw clay is inserted into the water and then kneaded on a mat spread on the ground with an appropriate amount of sieved donkey dung. It must be sieved since bigger pieces when burned may leave bigger cavities through which the water might leak. The ratio of clay to temper is determined intuitively. A very important stage of the production process is then kneading the clay by hand, with some water added to make the paste suitable for forming. ${ }^{8}$ The technology of shaping and firing is generally the same as in Jabarūna, with some small modifications only. The azyār are formed in the farmyard in

\footnotetext{
${ }^{8}$ Nabil Ali 2010: 356.
} 
7. Building middle part of the jar by applying thick coils of clay (Phot. P. Terendy).

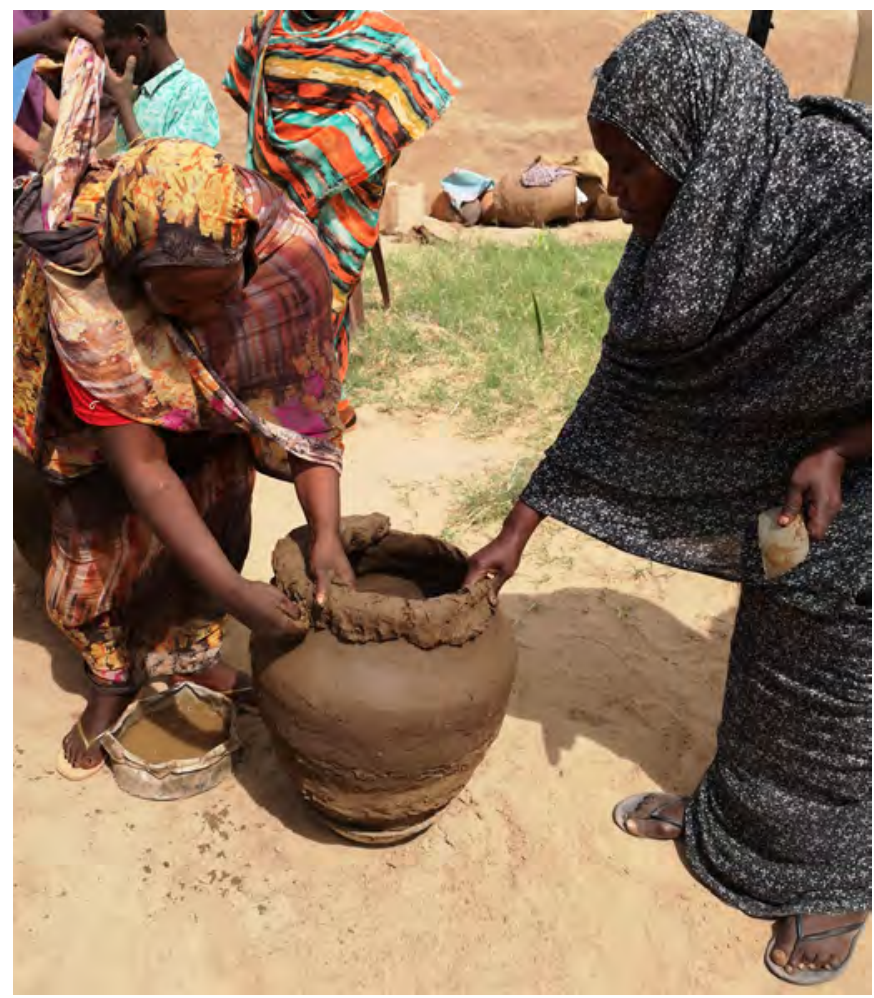

three stages over the three subsequent days. Azyār are prepared by using mixed techniques. First, the bottom part with a rounded base, is shaped from a lump of clay by pinching and pounding. The next day, after some drying of the base, the central part is shaped and after one more day, the upper part with the rim is made. The walls are built by hand by superimposing thick rolls of clay (Fig. 7) which are elongated by hand (Fig. 8) and finally scraped with the help of a spatula (Fig. 9). The fresh surface is burnished by a pebble. The finished azyār are left to dry under the sun and wind for three days and then moved for other three days into the shade. Finally, after six days the azyār are fired in a small hole situated next to the house, in the middle of the village. The production cycle takes place during the four summer months. ${ }^{9}$ The women produce 24 azyār monthly, but additionally, on demand, some other pottery products like qulal, censers, qawādīs for dovecots, water pipes, flower pots etc. are made. To achieve the desirable colour a yellow powder pigment is used, which dissolves only in water - unlike in Jabarūna - and is smeared on the upper part of the vessel. Therefore, after accomplishing the firing process, the two parts of a zìr

${ }^{9}$ In north-eastern Darfur pottery making was also seasonal, although the reason for firing ceramics only in the four months of summer is the agricultural calendar. Women used to start firing pots after the harvesting time was over (Arkell 1939: 85). 


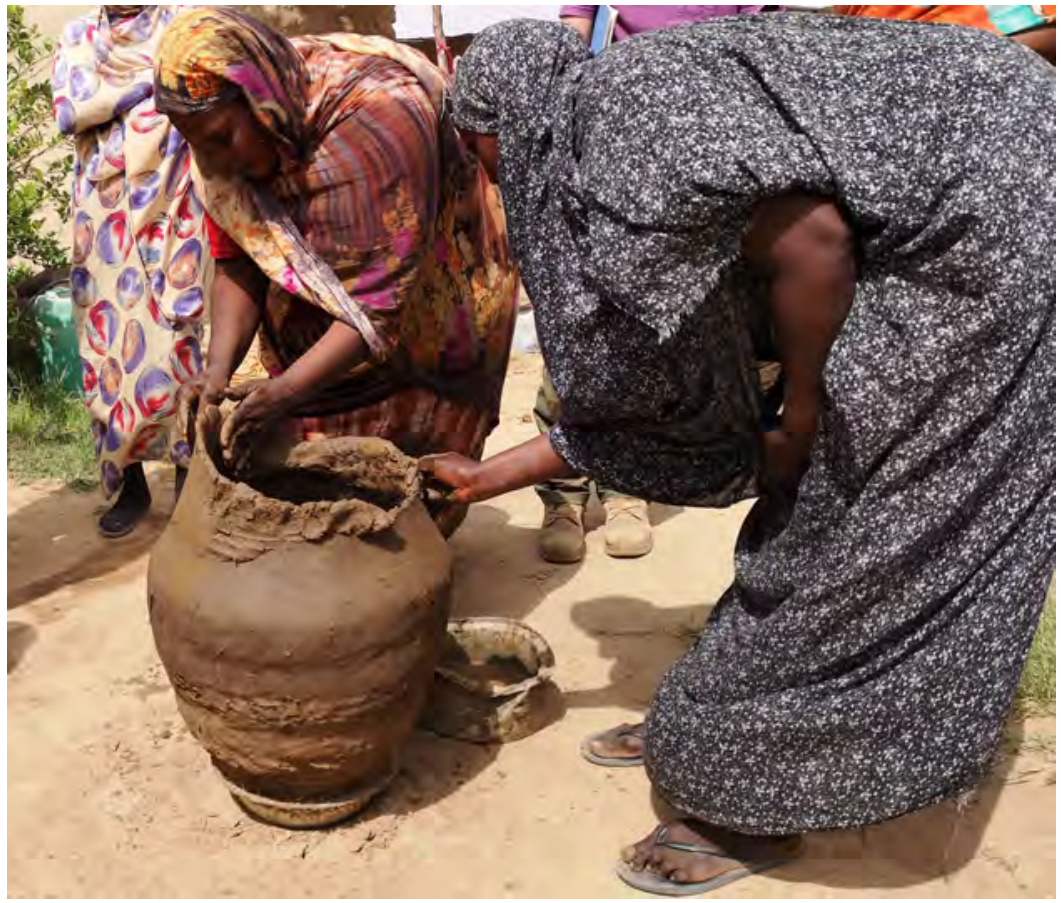

8. Pulling up walls of the jar (Phot. P. Terendy).

9. Scrapping and smoothing the outside and inside walls with the help of a spatula (Phot. A. Cedro).

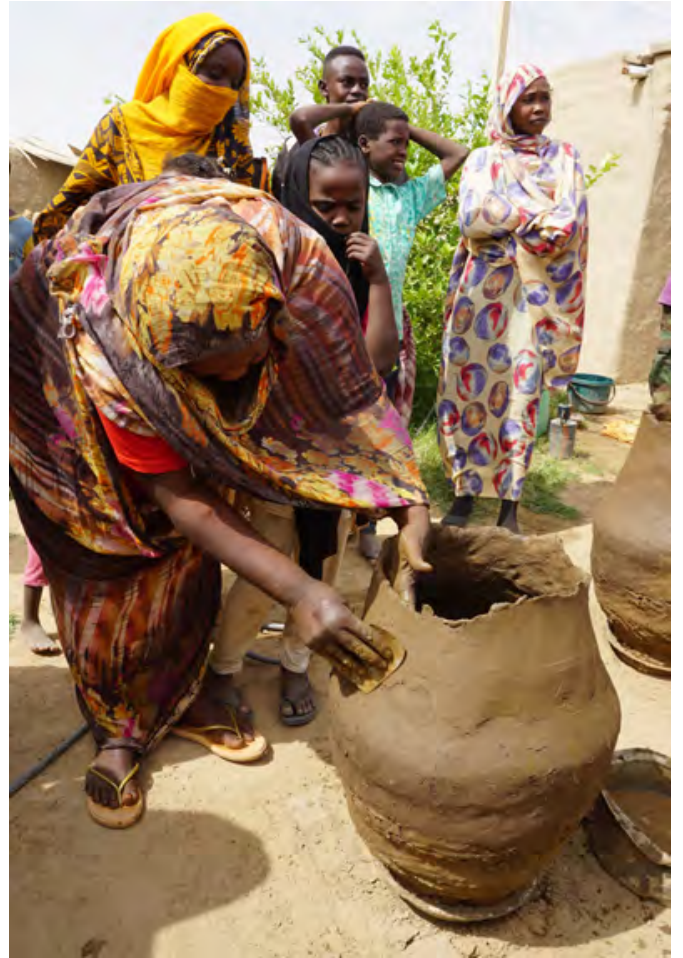


differ considerably in colour. However, the qawādīs made for dovecots are smeared with a smaller quantity of pigment and the final surface colour is therefore more uniform.

The pottery-making techniques used by the women from Jabarūna and Rūmī Bakrī belong to a very old and widespread tradition known and described by travellers and researchers in many other parts of Sudan. ${ }^{10}$

The Jabarūna pottery workshop is a good example of a localised production centre, in the past one of the biggest in the researched area. The Jabarūna and Rūmī Bakrī workshops prove that hand-formed pottery can be manufactured as a side occupation by local women, who are also involved in other gendered chores. The dense network of such local production centres has limited the trade of ceramics to the bare wheel-thrown forms which were produced in the specialised workshops led by men.

The production of pottery in Jabarūna and in Rūmī Bakrī fits into the definition of a 'household industry'. ${ }^{11}$ The other place of pottery production researched in 2015-2019 is located in Ad-Dabba and represents a 'workshop industry', where production is conducted by skilled male potters on a much bigger scale and therefore for a wider market.

\section{WORKSHOP INDUSTRY - AD-DABBA}

Understandably enough, the bigger centres housed bigger potteries, which served more numerous populations. The biggest centre of traditional pottery making in the Southern Dongola Reach is located on the outskirts of Ad-Dabba, today a commercial centre and a seat of the local government, in the past a traditional river terminus for caravan trade with the South located near the Nile estuary of Wādī al-Malik.

In the course of a series of interviews, it turned out that the manufacturers of ceramics - the workshop owner Ar-Rašīd 'Alī, his father Muhammad 'Alī and brother, Aḥmad 'Ali - are descendants of Nigerian Hausa migrants. Their ancestors migrated from the Sokoto State in the north-western part of Nigeria. ${ }^{12}$ They went on a pilgrimage to Mecca and never returned to their homeland. In the past, a decision to go on a pilgrimage meant leaving the homeland forever. Difficult living conditions in the Nigerian Sahel did not encourage return. Ancestors of our potters first settled about 150 years ago in Sennar (Sinnār) on the Blue Nile, c. 600 kilometres to the south of their present habitation. Sennar was a thriving agglomeration already in the early nineteenth century when it had a population of 100,000. Its importance grew and the population expanded. Commercial and agricultural activities in the town were spurred after the Sennar Dam was completed in 1925. In the early days of Anglo-Egyptian Condominium, it assimilated a huge wave of migrants, who over time moved from there to other destinations in Sudan. The history of the ancestors of Ar-Rashīd

10 See: Arkell 1939: 79-88; Haaland 1976: 47-61.

11 Leeuw 1977: 70.

${ }^{12}$ Northern Nigeria is one of the three regions in sub-Saharan Africa where pottery is handmade both by men and women, predominantly from Hausa ethnic group (Stössel 1984: 67). According to the Census of Nigeria of the year 1931 among the Hausa speaking potters of the Northern Province there were 909 females and 176 males (Stössel 1984: 67). 
'Alī's is typical in this respect. Nigerian potters brought to the Sudan knowledge of indigenous ceramic manufacturing, ${ }^{13}$ which is currently continued by their descendants in Ad-Dabba. Interestingly, they have preserved their identity and still cherish their traditions, communicating with each other in the Hausa language. According to their testimony, large groups of Hausa people are also living in Wād Madanī, Kassala, Al-Qaḍārif, Kūstī and Ad-Damāzīn.

Our manufacturers, before they finally settled in Ad-Dabba in 2003, lived at Shendi (Šandī), Ad-Dāmir, 'Ațbara, Barbar, Abū Hamad, Marawī, Karīma, Al-Qurayyir and in New Dongola.

In Ad-Dabba they live in extremely humble circumstances, but have radio and regularly read newspapers. They also habitually visit their families in Sennar. According to their accounts, the Hausa manufacturers of ceramics today perform their trade in Marawī and Ahmad 'Alī, the younger brother of Ar-Rašìd, has opened his own business in Abū Hamad. The research conducted at Ad-Dabba confirms a close resemblance to the pottery techniques used in the workshop in Karīma (about $160 \mathrm{~km}$ away). ${ }^{14}$

For manufacturing the pots, a silt alluvial sediment (turāb damīra) is used. It is transported from the banks of the Nile where it occurs in two varieties - a black, heavy clay and red, light clay. The alluvial deposits are accessible by a low water level in the river. From May to August during the Nile inundation its exploitation is not possible. Therefore it is necessary to have some volume of clay on stock, especially for the summer months. The yellow, hard clay present on the spot where the workshop is situated is not suitable for forming pots. The different sorts of clay give the different colour of the pots' surface after firing. To prepare the paste for making vessels, the raw clay is mixed with organic temper composed of donkey dung which quite easily turns into fine-grained powder (Fig. 10). Chopped straw is added to improve the plasticity of the paste and to reduce shrinkage of the clay during firing and drying; it also results in a more porous body of the final product. The clay paste for forming vessels is prepared in a special pit dug into the ground at the site. Clay, dung and an appropriate volume of water sufficient for forming 60 azyār are mixed there. The ready clay paste is left for one day before using it for forming pots.

There are essentially four types of vessels produced in the Ad-Dabba workshop: large azyār, medium azyār, globular qulla-type jars - of large and small sizes and the flower pots (zuhriyāt, sing. zuhriya). All vessels are hand-made but, depending on the size and shape, mixed techniques are employed during their forming process. In the first stage of making a large zīr a potter puts a lump of clay on a convex mould, a rounded base of another pot, or a specially prepared form (Fig. 11), and then presses it by hand or by using a wooden slat and finally scrapes the surface with a small plastic or metal sheet (Fig. 12). When the required shape is achieved and the thickness of walls is even, the base of zir is

\footnotetext{
13 See: Gosselain 2015.

14 Garcea 2004.
} 


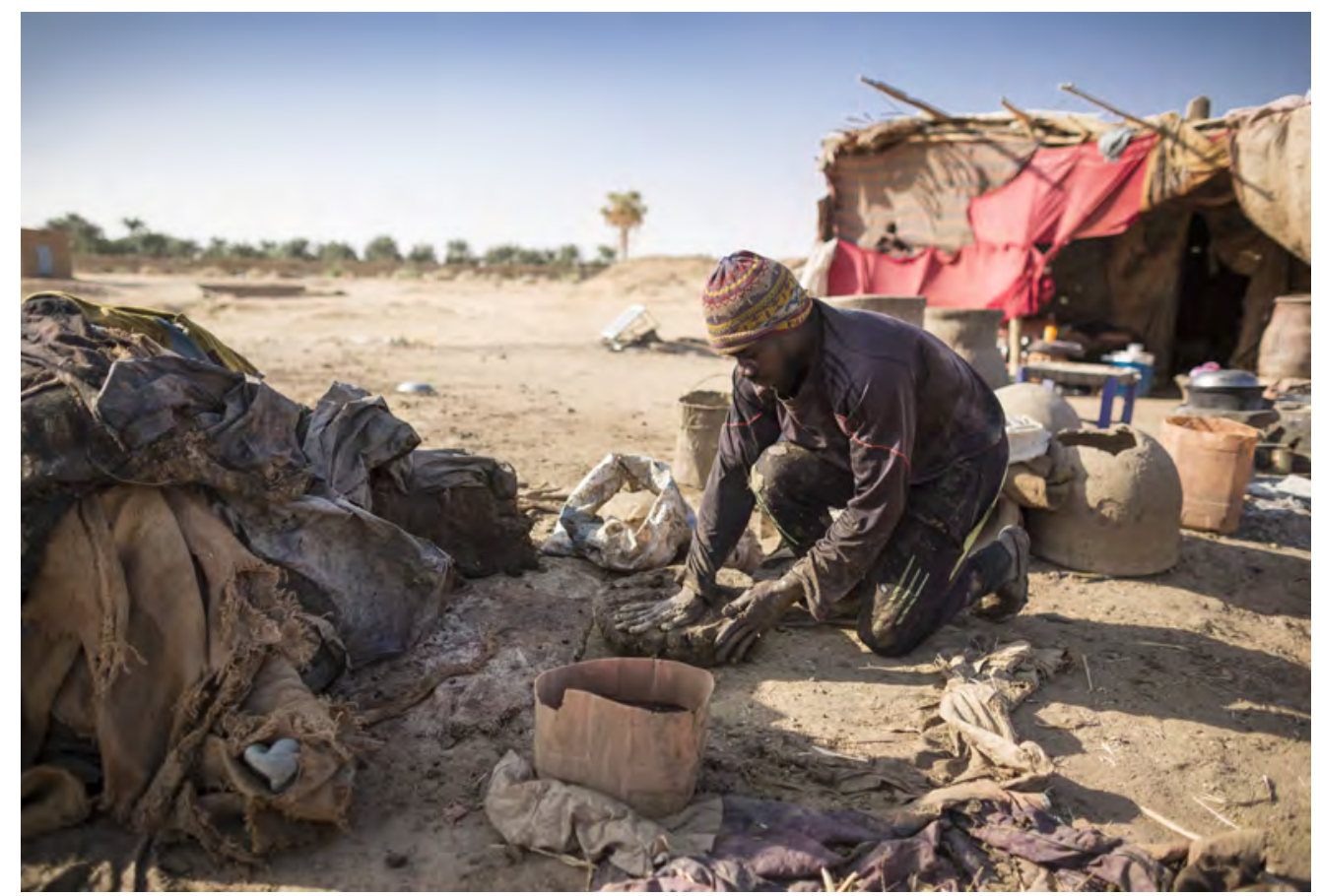

10. Mixing alluvial silt with animal manure (Phot. A. Chojnacki).

turned upwards and set properly in the sand (Fig. 13). After removing the mould (Fig. 14) and a short period of drying the upper part of the jar is built. First, the edge of the base part is thinned with the help of a wooden paddle (Fig. 15) and then large rolls of clay are superimposed and pinched with fingers (Fig. 16). A thick ring of clay is elongated and flattened with a drawing motions of the hands (Fig. 17). By repeating these moves a few times the potter pulls up the wide shoulders and neck of the jar (Fig. 18).

Firing is done in the pit in isolation. It is arranged in a shallow, trough-shaped recess in the ground (Fig. 19). The pots are put on a layer of dried animal dung. The kiln filled with pots is then lined from above and from the sides with large fragments of broken pottery vessels and with huge ceramic slabs made for the purpose (Figs 20-21). Occasionally, large worn-out sacks (šawwālatt, sing. šawwāl) are used as additional fuel. Over them, another layer of manure is spread. Palm twigs are used to ignite the bonfire. The kiln is set alight from the top, the fire penetrates then the lower layer of manure (Fig. 22). The pots should be fired practically without contact with air, which causes cracking of the pots. Most important is to keep the temperature of firing constant - over intensive firepower leads to deformation or cracking. 


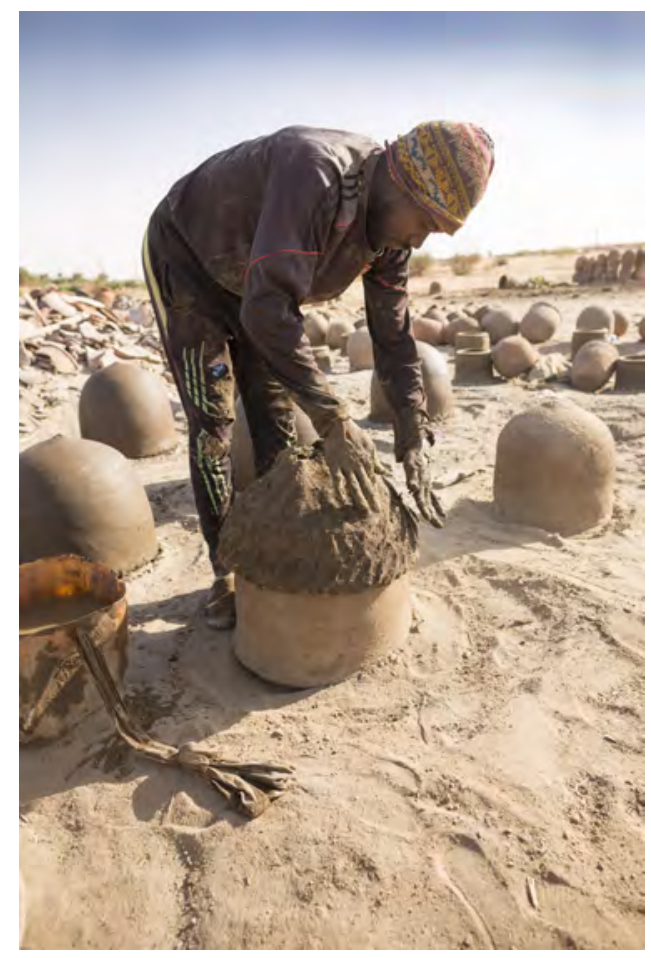

11. Squashing a lump of clay on top of the ceramic mould (Phot. A. Chojnacki).

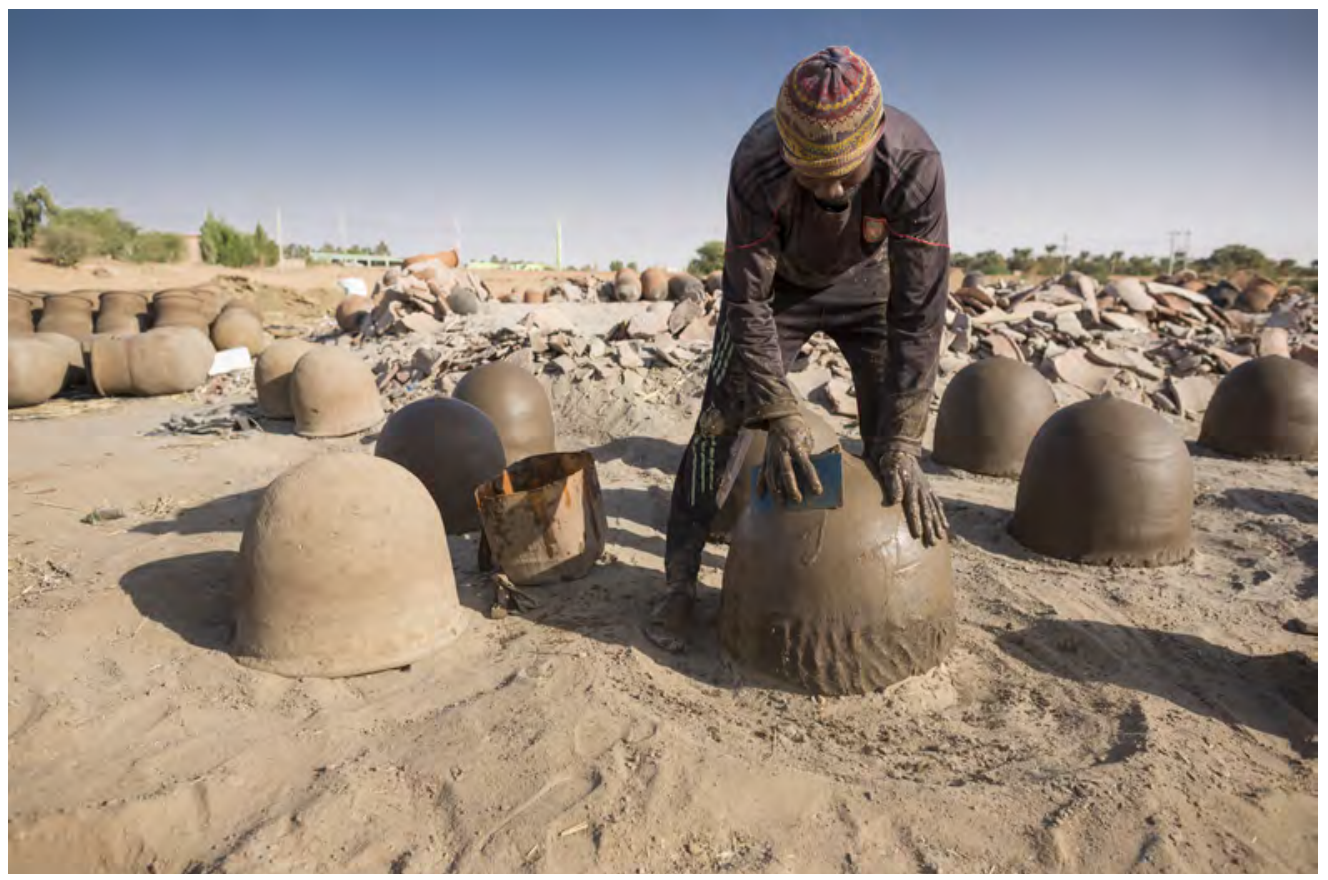

12. Forming the bottom part of a zìr on the mould (Phot. A. Chojnacki). 


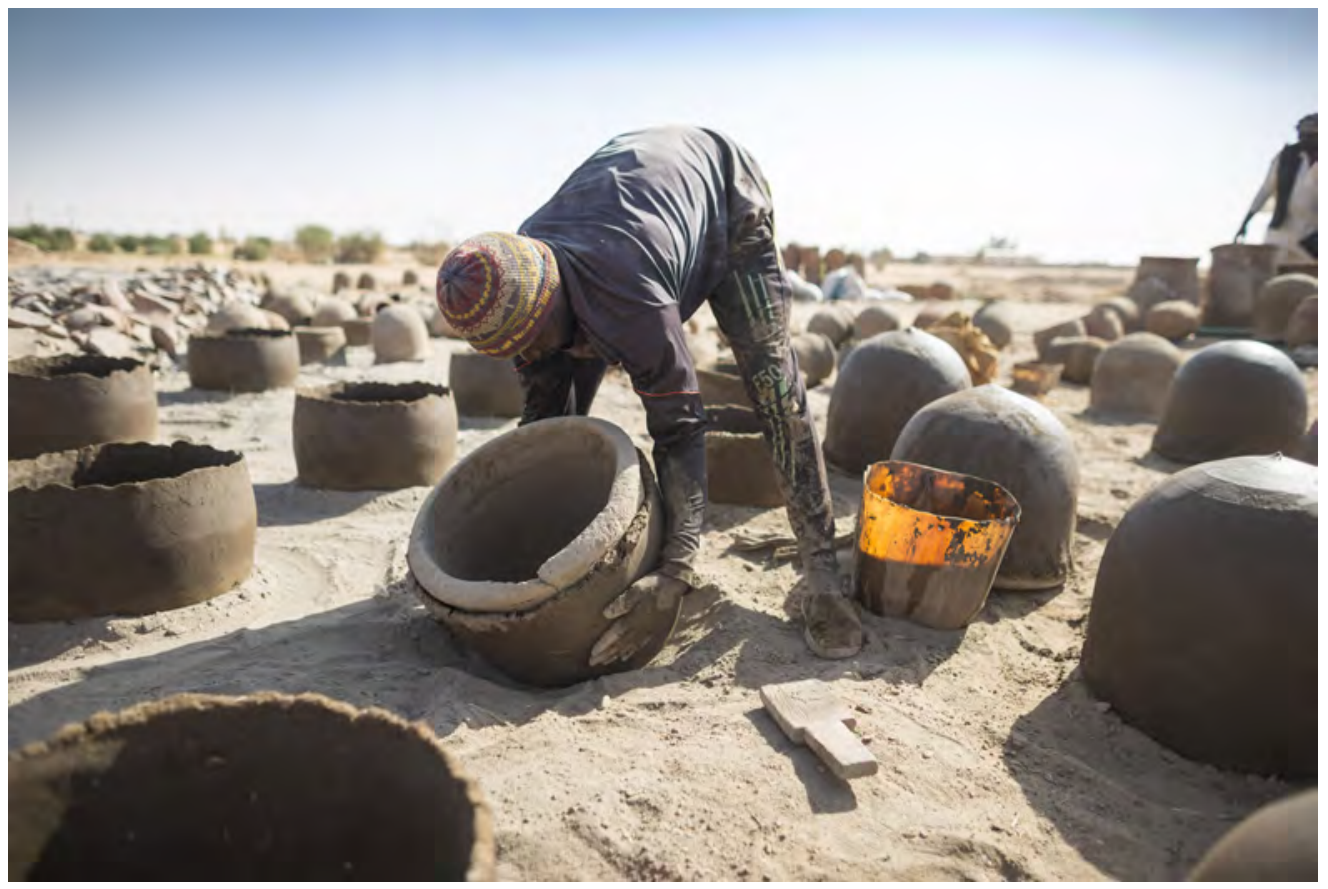

13. Turning upwards base of a jar with a mould still stuck inside (Phot. A. Chojnacki).

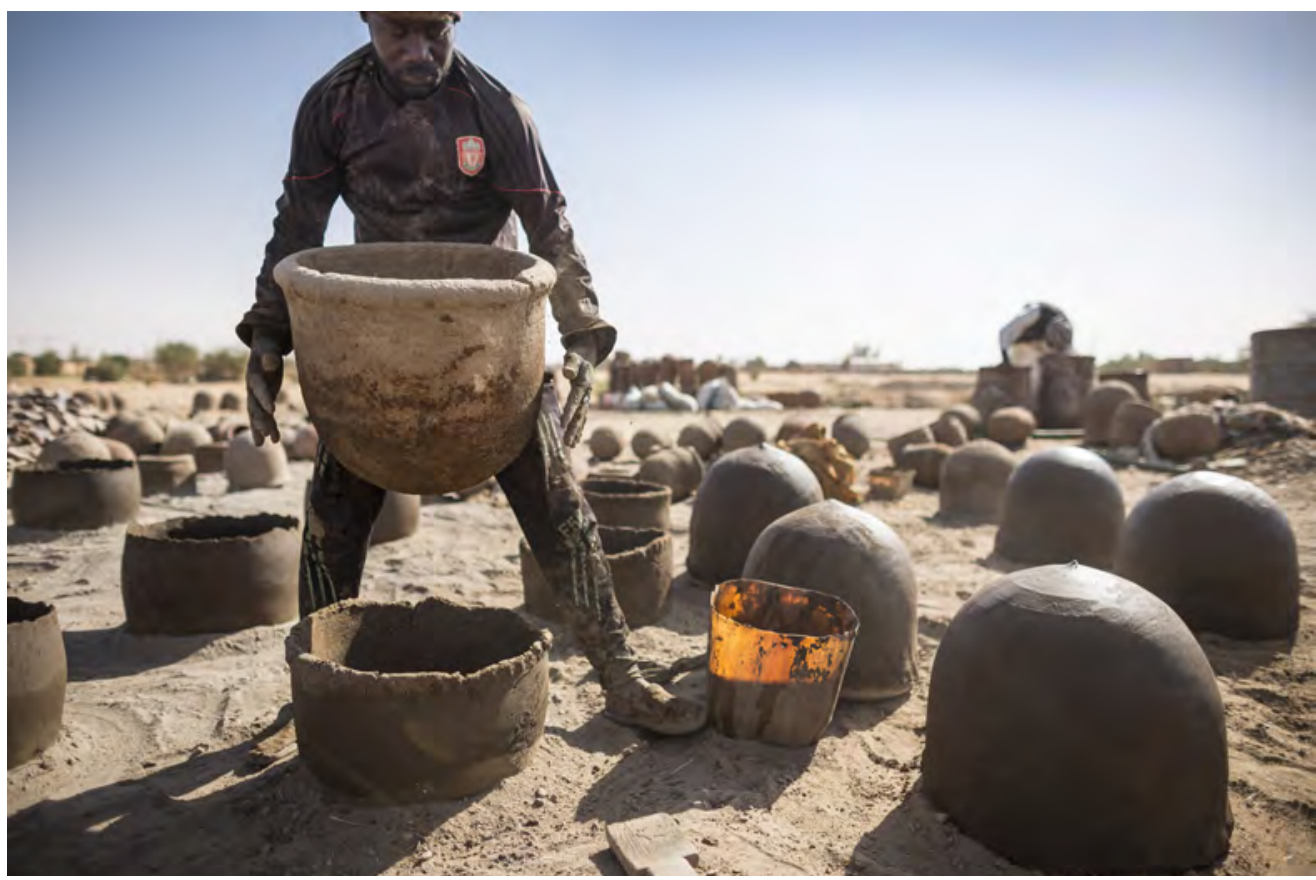

14. Removing the mould (Phot. A. Chojnacki). 


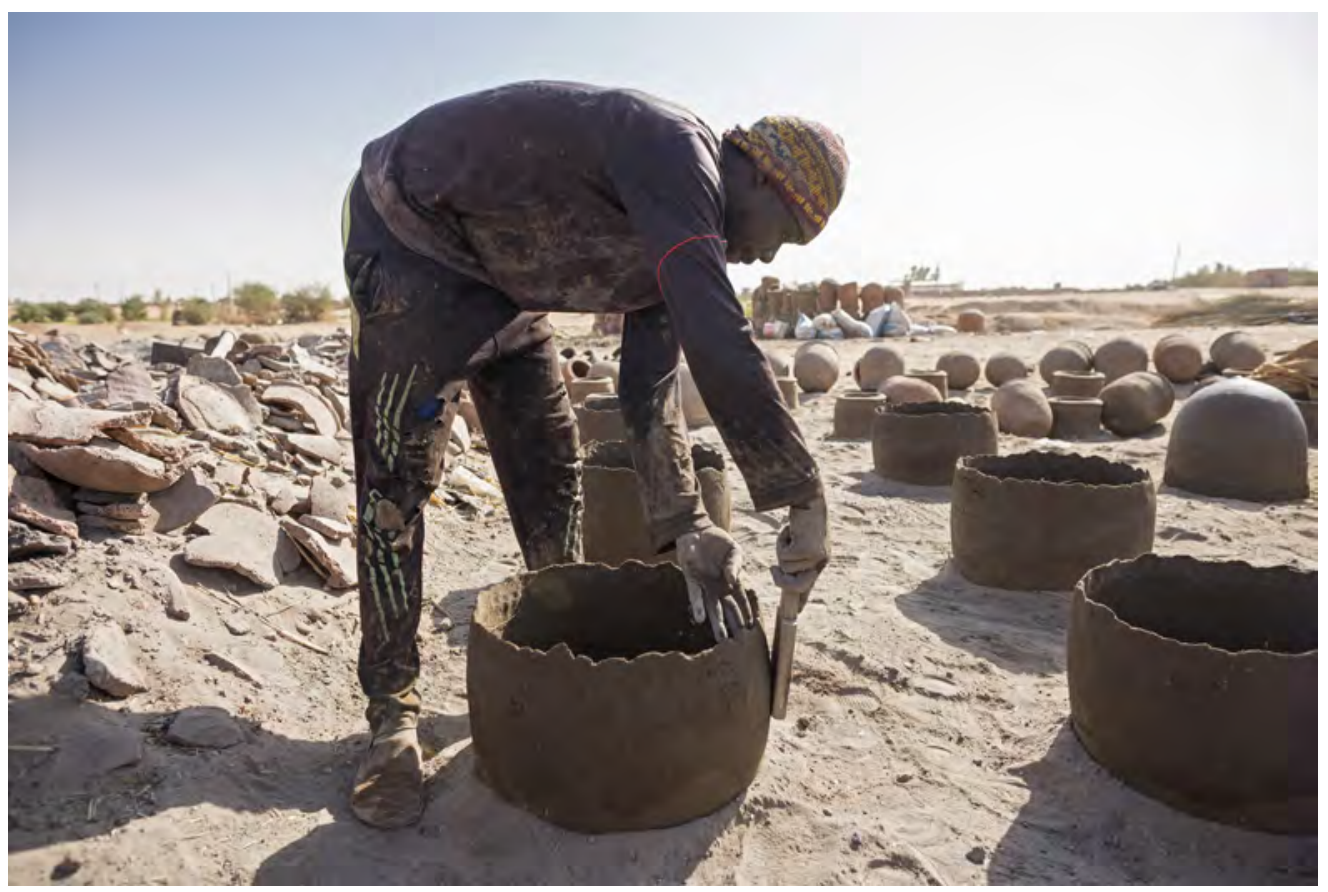

15. Thinning the edge of the lower part of zìr with a wooden paddle (Phot. A. Chojnacki).

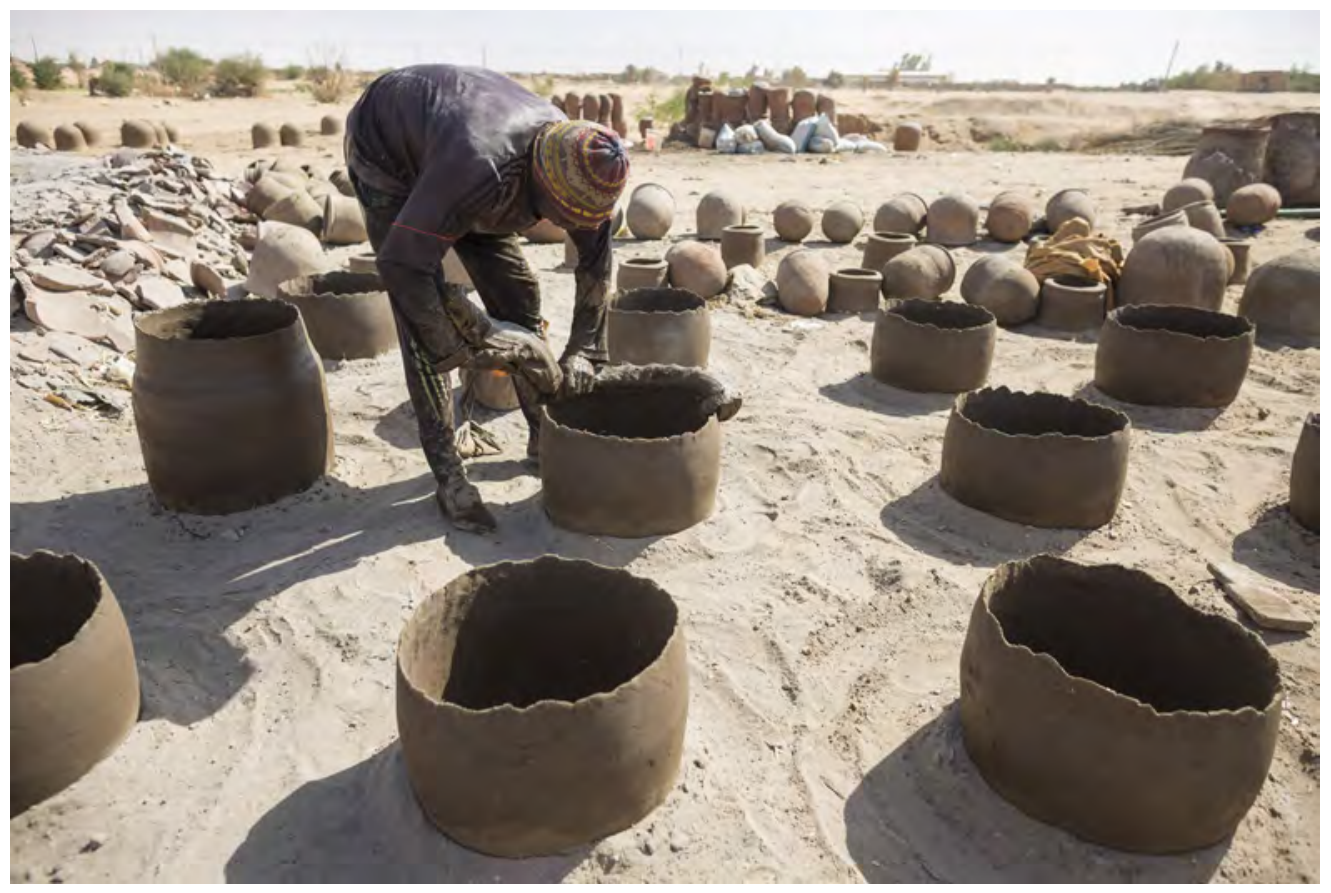

16. Adding thick rolls of clay to the lower part of a jar (Phot. A. Chojnacki). 


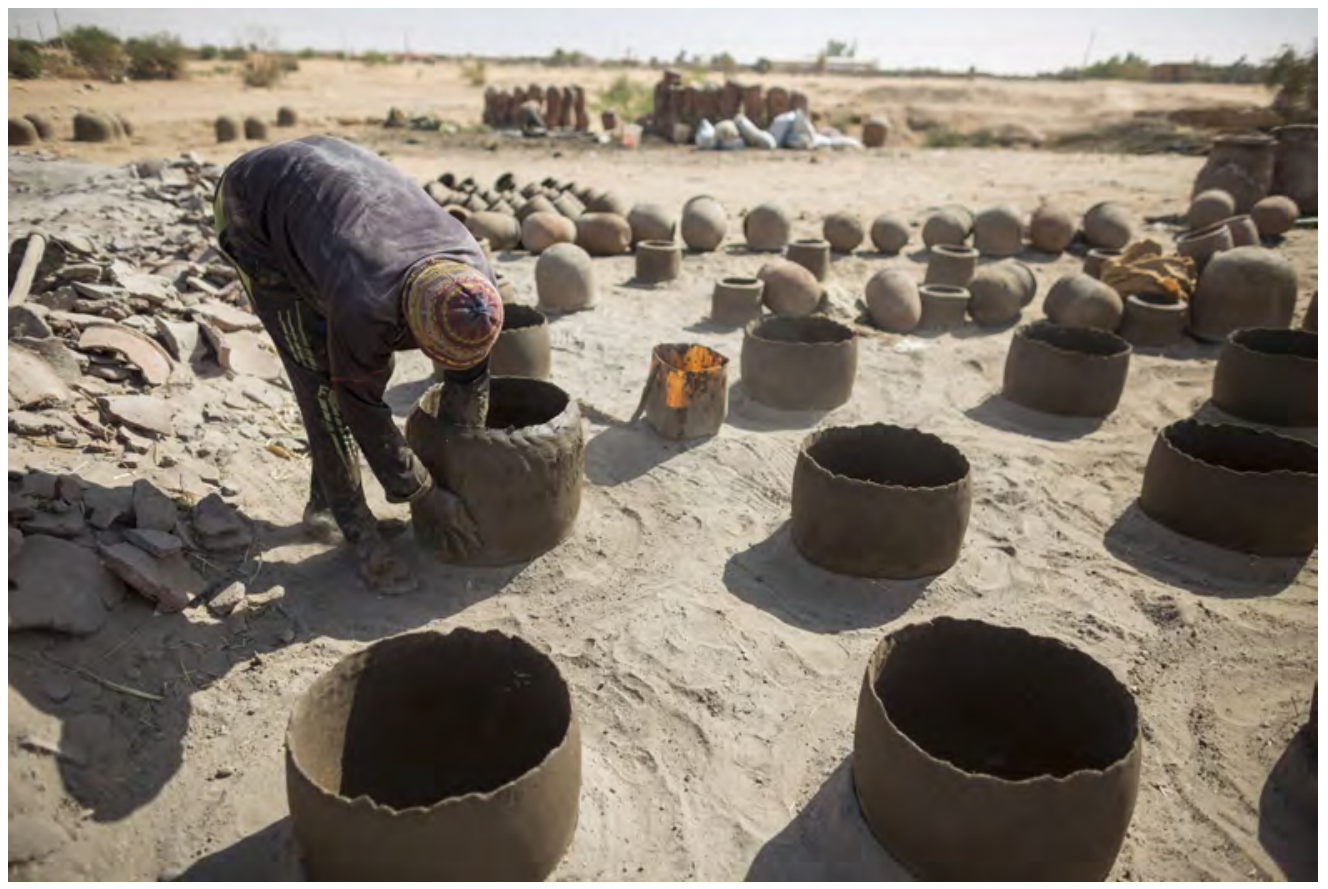

17. Pulling up walls of a jar with drawing motions of hands (Phot. A. Chojnacki).

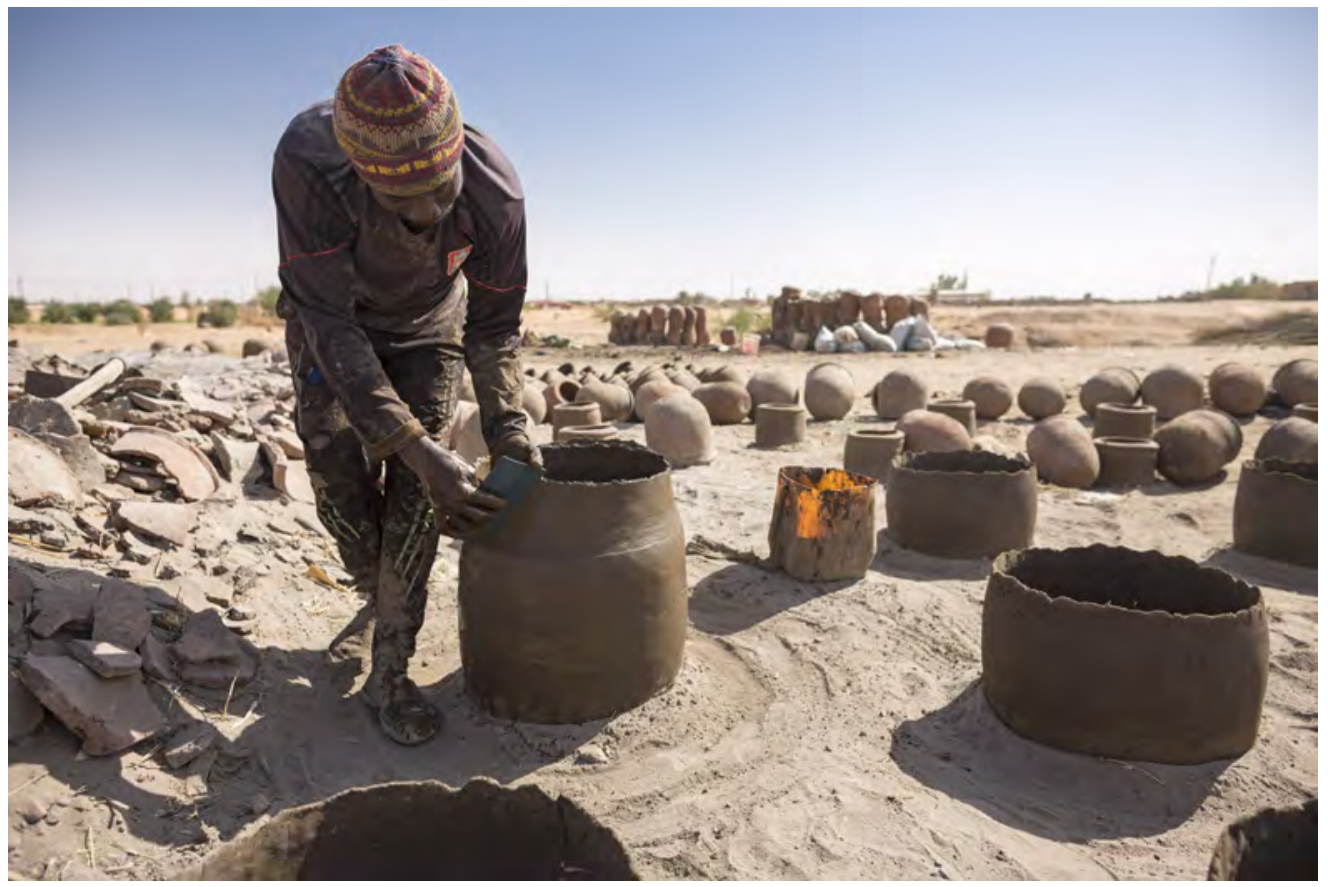

18. Scrapping the surface with a spatula (Phot. A. Chojnacki). 


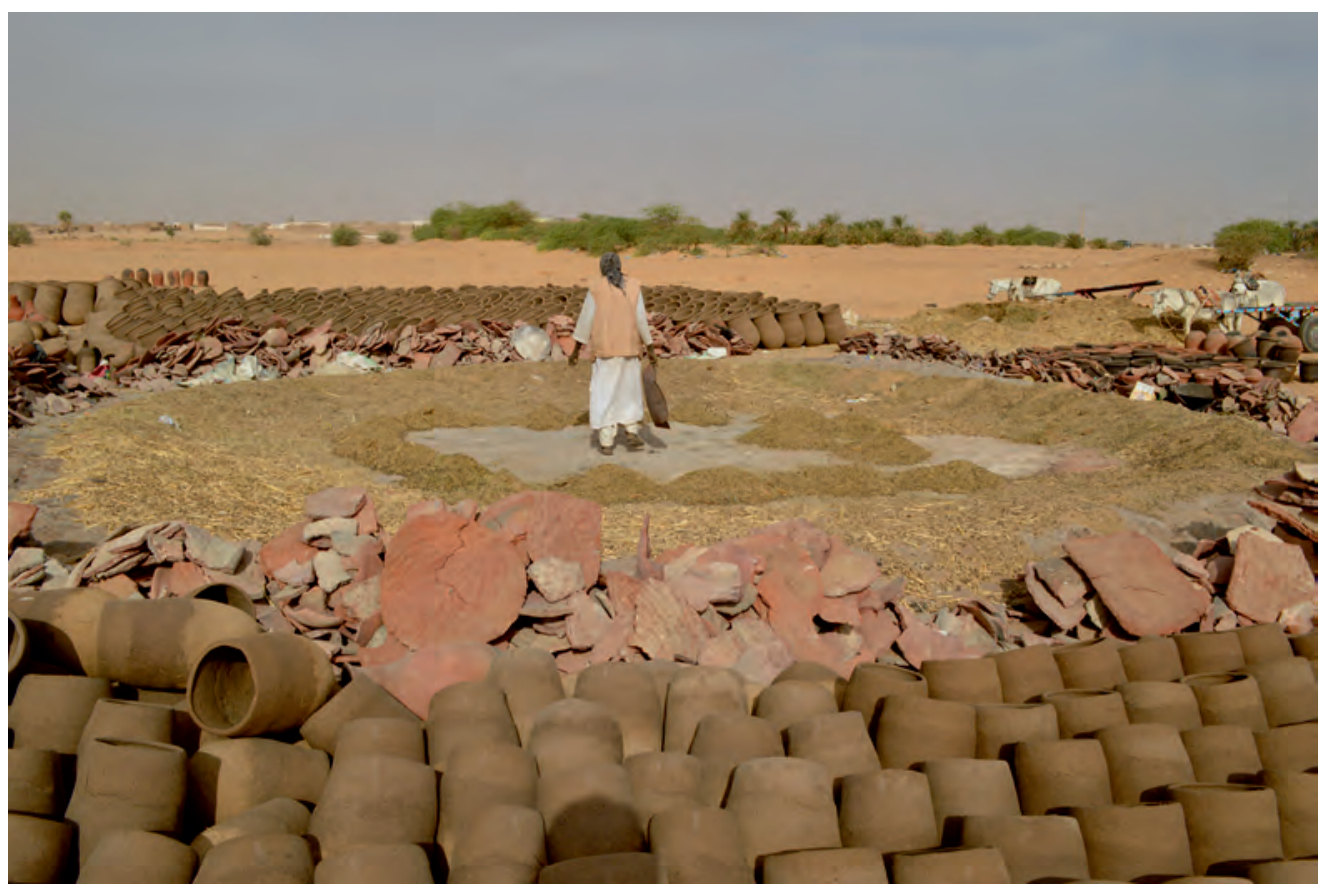

19. Preparing firing place by spreading manure on the ground (Phot. A. Cedro).

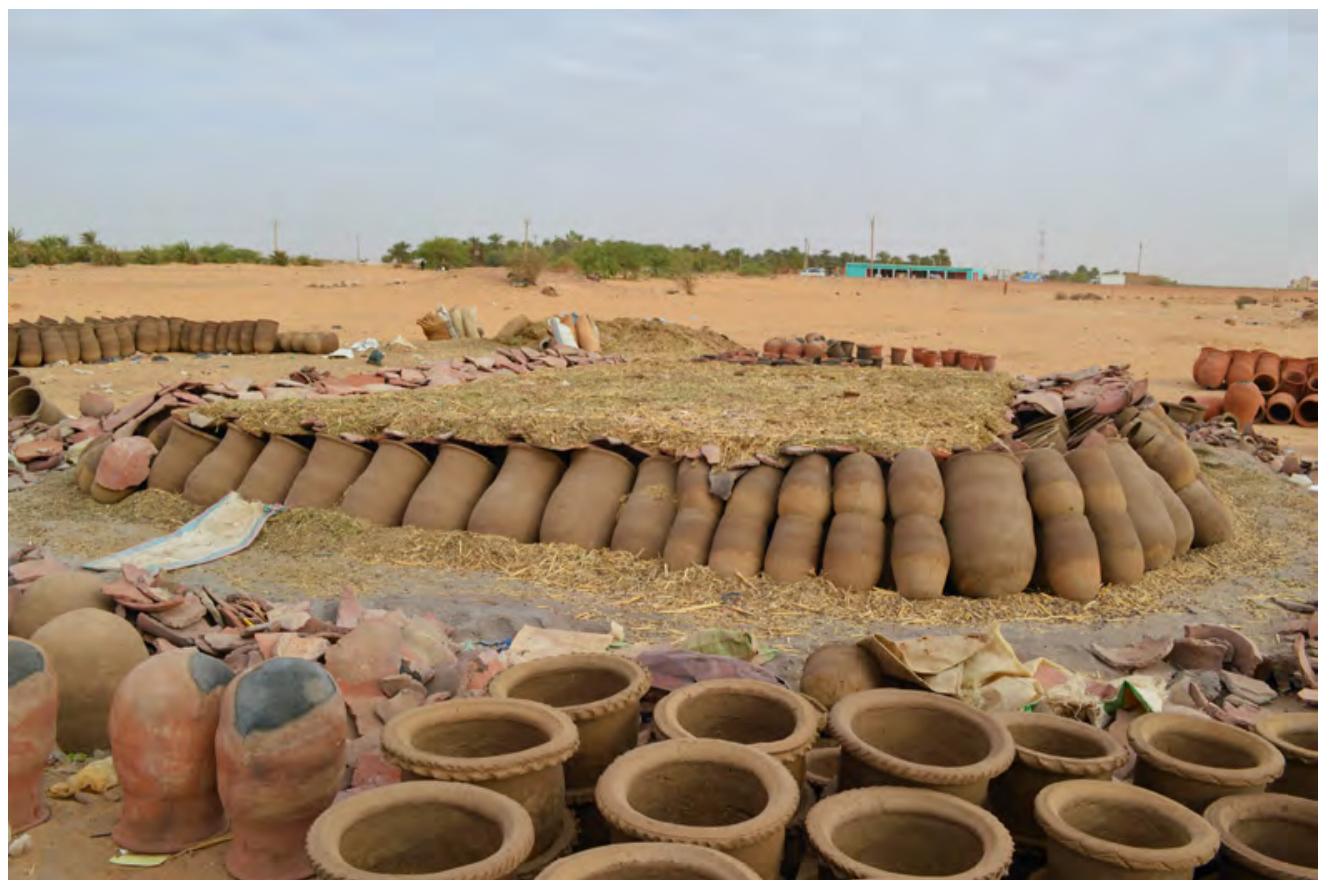

20. Vessels at the firing place are arranged vertically, smaller jars are set in two layers (Phot. A. Cedro). 


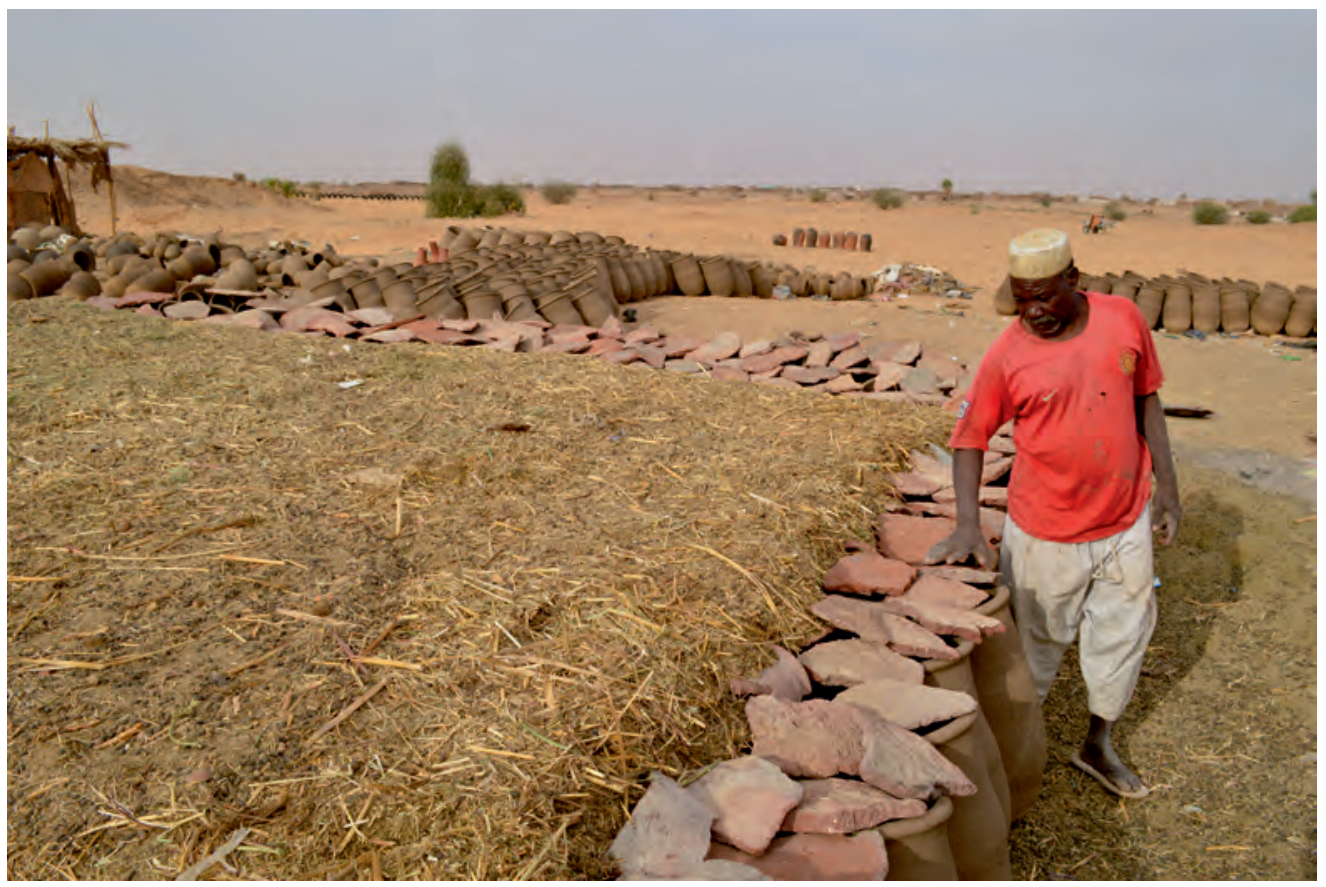

21. Covering the jars with ceramic slabs and layer of manure on a top (Phot. A. Cedro).

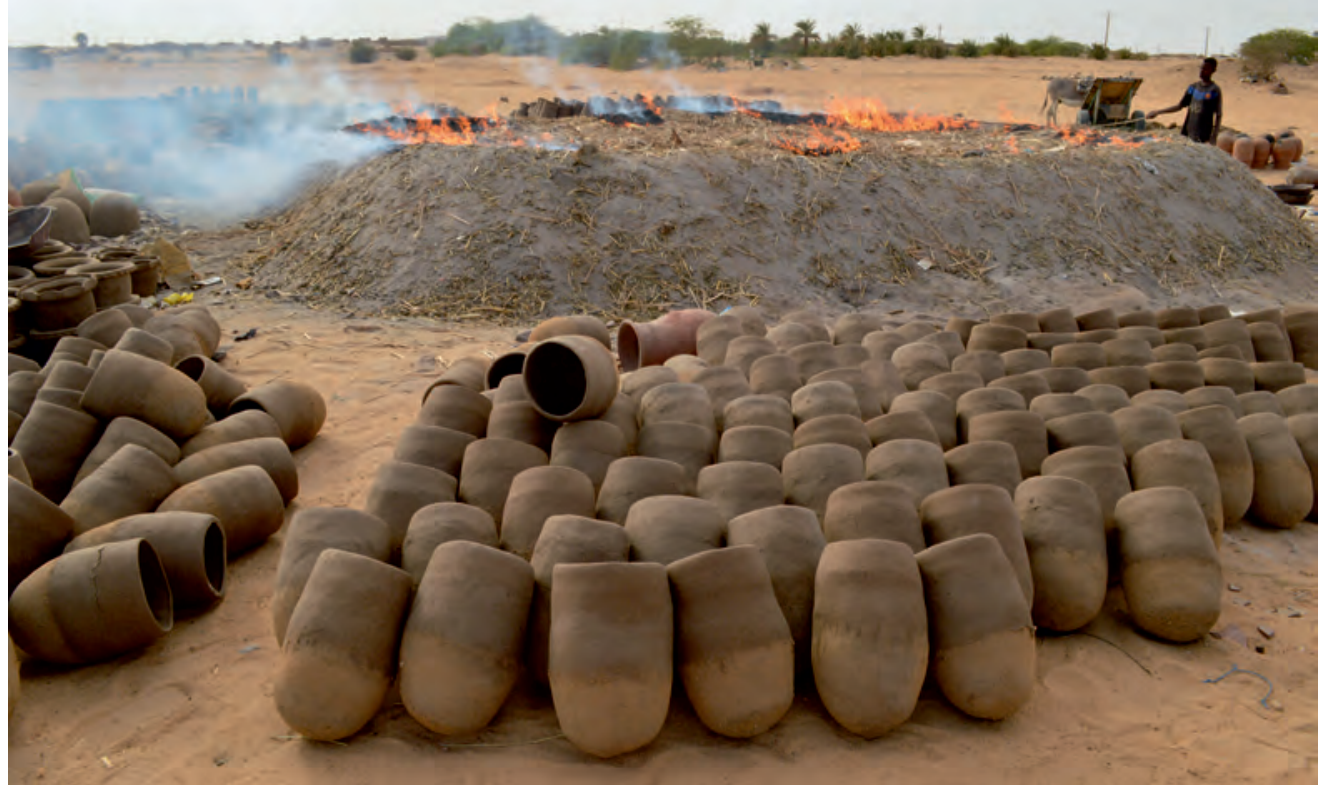

22. Igniting the fire; in the foreground middle jars for dukhān are drying (Phot. A. Cedro). 
For firing 100 azyār an average of 300 sacks of manure is needed. However, not all types of manure are of equal quality and used in equal measure. The required volume depends also on the sort of clay - the black, heavy clay requires stronger fire and the red, light clay needs less fuel. Large quantities of vessels are fired during the summer only. Hot weather is conducive to achieve a higher temperature in the 'oven' at the lower cost because less fuel is needed. Sustaining the firing process is therefore much cheaper than in the wintertime. In the summer the demand for pots used for cooling water is higher. That is crop time for the potters. Over the winter period fewer vessels are fired but it is also a season of full-capacity utilisation.

Large vessels are placed in the oven vertically, mouth up, in one layer, smaller ones can be laid in two layers, also vertically (see above, Fig. 20). Firing takes usually one day - when using the sacks as additional fuel it can take even only half a day; a longer firing period might result in cracks. After firing, vessels cool down for two days, then the covering layer can be removed and they can be taken out. A vital role in firing is played by the wind. If there is no wind a successful firing brings $100 \%$ good pots and with wind $70-80 \%$, but sometimes not more than $50-60 \%$ of the oven content is suitable for sale. The wind also influences the surface colour. If, for example, the wind is blowing from the south the azyār in the southern part of the kiln will take on a more reddish colour due to the stronger fire from this side. During one of the visits in the workshop, we observed a number of azyār with partly burnt black bottoms. According to the received information (from Ar-Rašĩd), this was caused by a very strong wind blowing during the firing. The vessels which were fit for use were fired again in a small kiln. Before the firing starts dried leaves of a desert plant called tušši $q$ were put inside and ignited. The additional firing makes the surface colour of the vessel uniformly black.

After removal from the oven, each vessel is immersed in water. This is the initial phase of a process aimed at obtaining the correct porosity of the pot's surface. To achieve good results the potter blends $0.5 \mathrm{~kg}$ of cement with $0.5 \mathrm{~kg}$ of sherd powder and $0.25 \mathrm{~kg}$ of powdered red paint. A handful of this mixture dissolved in five litres of water is sufficient to slush the inside of four large azyār. Cracked surfaces are repaired with a paste made of clay and grog (powder from crushed sherds). Laid on the damaged surface it dries in a few hours.

Ad-Dabba manufacturers sell annually from one thousand to two thousand vessels on a fixed price: for a large zīr, they charge (in February 2019) 200 Sudanese Pounds (which then equal to 4 USD), for the medium-sized zīr 150 SDG, large qulla 70 SDG, flower pot 60 SDG, jar for the dovecot 50 SDG and for ornamented (painted) big ceramic wares intended for pure decorative purposes, made on special order, 250-300 SDG.

\section{A DYING CRAFT}

Traditional pottery making is becoming an extinct craft all across Africa and the Middle Nile is no exception to the rule. The elders from the right bank village of Al-Qadār, near Old Dongola, recollect that in the past more Dongolawiyat were occasionally involved in 
pottery making for their own use and for their neighbours. ${ }^{15}$ The last ones, 'Azīza Mabrūk and Halīma Sa'ad passed away less than ten years ago, at the age of eighty. ${ }^{16}$ Although their mothers and grandmothers were making pottery they left nobody who might continue their craft. The art of handmaking pottery objects for local needs belonged in the past to the everyday activities for women in most of the localities within the researched area. Pottery making was always regarded as a female occupation in Al-Qadār. In the case of above mentioned 'Azīza and Halīma, it was their main occupation and made them financially independent from their husbands, who hardly made ends meet working in the field. Both women were neighbours and shared a workshop on the outskirts of the village half a kilometre from the Nile.

According to Abū l'Qāsim Ḥasan Ziyāda, a villager of Al-Qadār, it usually took them two days to make one zīr. They used to manufacture three or four azyār at once, since demand was small, due to the many producers in the neighbourhood. With time, they gained widespread renown and people from other villages were coming to their workshop to purchase their pots. They produced the traditional large water jugs (azyār) but also wide, round, vessels called kubīq used in the watering of domestic animals and kneading the dough at home as well as to keeping dates for Ramadan, the universally used censers and qullas, large wide dishes called kabarūs and the $d u k k a^{17}$ (in Sudan-Arabic doka) vessel for preparing kisra. ${ }^{18}$

Soon after the Al-Qadār workshop was abandoned, production also ceased in the left bank pottery at Al-Ghāba, vis à vis Old Dongola. The Al-Ghāba workshop, noteworthy located close to Jabarūna, supplied a vast area with excellent azyār which are still in frequent use.

In Tanqasī also active as a woman-potter was Al-‘Izqīna, who made small azyār, qulal, incense burners, cooking pots (qidr, qidra) and until 1950 pots called kantū̌s for preparing the traditional dish mulāh or keeping milk. She fired the pottery in a small kiln mound by using manure as fuel. After she died at the beginning of the 1960s nobody continued the production.

${ }^{15}$ At least three informers were questioned about the extinct workshop in Al-Qadār. Their testimonies, although relevant to the quite recent past, differ significantly. Here, we decided to base our relation on the version provided by Abu l'Qāsim Hassan Ziyada during interview with Bogdan Żurawski.

${ }^{16}$ A different account was given by Al-Fụil Ḥasan, a teacher of English, on the 26 ${ }^{\text {th }}$ February 2019. According to him 'Azīza died about 25 years ago. She worked together with her daughter who did not take over the workshop.

${ }^{17}$ Large clay plates used today for baking kisra bread were discovered also on Meroitic sites dating to about 500 вC (Dirar 2015: 25-26).

${ }^{18}$ Traditional pancake made of sorghum. In the old days, according to the Abu l'Qāsim's account, kisra prepared in dukka was a luxury. Some types of breads like tukkab were prepared by nomads directly on the soil without using pottery vessels (Dirar 2015: 218-219). 


\section{POTTERY MAKING, A FEMALE JOB?}

Suggesting that pottery making in the Ad-Dabba Bend is and was a typically feminine occupation would miss the truth. Although at the moment there is only one pottery workshop run by men, there were more in the recent past.

One of the bygone male potters is 'Abd aș-Șādiq Sīdū, who now lives in Banganarti. In the past, he had a pottery workshop in Jazīra Tanqasī. After the disastrous flood in 1988, he moved to Banganarti but managed to restore his workshop in the Jazīra and to continue firing for about six-seven more years. However, he used a different firing technology and another type of clay to that preferred by the female potters of Jabarūna and Rūmī Bakrī. Instead of alluvial silt (turāb damīra) from the river bank, he manufactured the pottery wares using some wadi clay (called by him țin ațūniya). Its outcrops were close to his workshop. He fired pots in an oven sunk deeply in the ground using pieces of wood as the only fuel. After the firing process was accomplished, the azyār were filled inside with river mud mixed with water to achieve the right porosity. Then they were filled with water to check if the permeability was sufficient. The azyār made by him had a mostly dark (black) surface but, on request, these could also be brick-red. Usually, he was firing ten azyār per week, working six months of the year as a potter and the rest of his time spending in the field. He was also the main supplier of qawādīs used for dovecots. At present, at home he uses azyār made by him and even by his father. Water containers and other ceramic forms made by them are still in use among residents of Banganarti and Hammūr.

In another part of Tanqasī, Tanqasī Hilla was the well-known pottery manufacturer, Ḥasan Șabāh al-Khayr, who at first worked with his own father, who came from the Šayqīya tribe. Hasan was employed in the local schools, at the beginning as servant (farrās $\breve{\text { ) and }}$ later for very long time (until 1995) as water carrier (saqq $\left.\bar{a}^{\prime}\right)$. However, work at school left him a great deal of free time to burn clay-vessels in a hole in the ground using animal dung as fuel. He was living close to the big mosque, his old house is now inhabited, and his kiln was situated nearby, close to the river. He was a very religious man and chose this place because it was near to the grave (qubba) of the worshipped šaykh, Kandibar. Thus he could perform his job under his holy protection. 'Ișām 'Abd al-Lațif, son of the former school director in Tanqasī, knew Hasan from his school days and was able to show places related to his activities.

The other workshop run by a man was situated further upriver on the left bank, Al-Qurayyir. According to local informant, the workshop was still working in 2000. The owner was an elder man who fired pottery vessels in an oven four metres in diameter, closed from the top with a round iron lid. It was sunk deep into the ground, said to be $c$. five meter deep and could accommodate 30 azyār at one go. Pieces of wood were used as fuel. The Al-Qurayyir potter used the common alluvial silt from the river mixed with donkey manure as temper. In 2000 the man died and his workshop was closed. 
On the left river bank in Al-Ghāba there was a pottery workshop run by a married couple. According to the account obtained from the farmer Khaydar 'Awwūda from Hammūr, the man learned the traditional firing of ceramics from his mother and taught his wife to do this. For a long time they supplied inhabitants of neighbouring villages with water jars. The workshop was closed about five years ago after the producers died.

According to another account obtained from Aḥmad Muḥammad Rāba, a farmer and driver from Ḥammūr Bahrī, in the area of Hammūr Jazīra was a pottery workshop also run by a married couple. Aḥmad Muhammad Rāba has in his house a zīr made by them more than twenty years ago, which is still in good condition and in use. The couple had a hole for firing pottery situated about $200 \mathrm{~m}$ from their house. They used the common mixture of alluvial silt with donkey manure as temper. The only fuel was the dung. They could - according to the account - fire about 10-15 azyār at a time.

\section{SOME LESS KNOWN FUNCTIONS OF LOCALLY MADE CERAMICS}

The vessels manufactured by local potters are used for various domestic purposes. Large azyār are traditionally set in the streets, in a shadowy windy place in front of a dwelling mansion, at local bus stations, in cemeteries etc. All are destined to provide local residents and visitors with cool water during the hot days of summer (Fig. 23). Set in a farmyard, several azyār can serve to water vegetables, flowers etc. grown next to them (Fig. 24).

The azyār are also suited to long-term storage of different types of food, as e.g. dates and fish. Fresh dates harvested directly from the tree are put into the $z \bar{\imath} r$, closed with a sealed lid and tightly wrapped with a piece of cloth around the rim. In this way, they can be stored for a year or even longer.

According to 'Ațiyāt Djādū Manșūr, the female cook to the Polish Archaeological mission, species of small fish called in the Nubian language dabis (fasikh) are usually stored in zìr. The fish, thoroughly gutted, are rubbed with salt in baskets woven from palm branches. Then they are thrown into a round metal dish called dukka, with a diameter of approx. $50 \mathrm{~cm}$ put on low heat and rotated with a little hoe called karādīq until they are completely dry. After cooling the fish are placed in a zìr, which is closed tightly by a lid sealed with a piece of textile and can be stored for approximately one or two years.

In a medium-sized zīr (Fig. 25), a traditional dish called miš can be prepared. Miš consists of milk mixed with the following ingredients: olives (zaytūn), black cumin (kammūn), fenugreek ( $h u l b a)$, Italian fennel (šamār, šumra šāi'a), garlic and salt. Some red or green chili powder (šahțta hamra or šatța hadra) is also added. In a closed vessel it may be kept for a night and the next day; this traditional dish is ready-to-eat. It is completely different from the traditional Egyptian miš, which is a cheese made by fermenting salty cheese for several months or even years.

The jars (qulal) inserted into the walls at a certain height are also used as coops for dove.

The traps (ašrāk, sing. šarak) for rabbits are similar to the small azyār but have a more elongated body, widening downwards, and relatively narrow orifice (Fig. 26). 


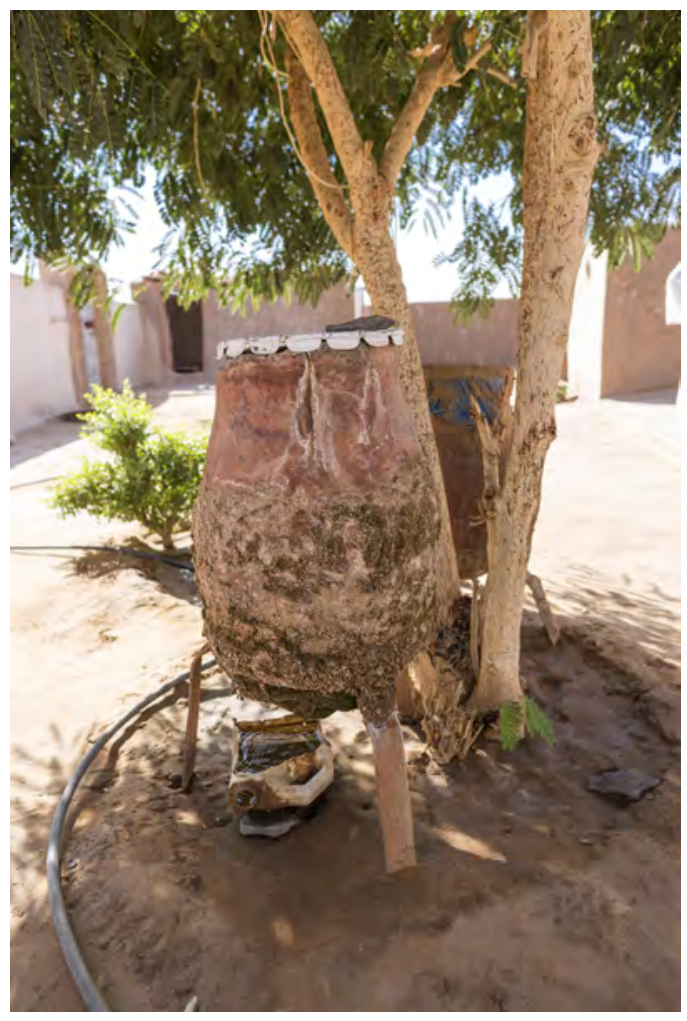

23. Azyār for drinking water placed in the house courtyard (Phot. A. Chojnacki).

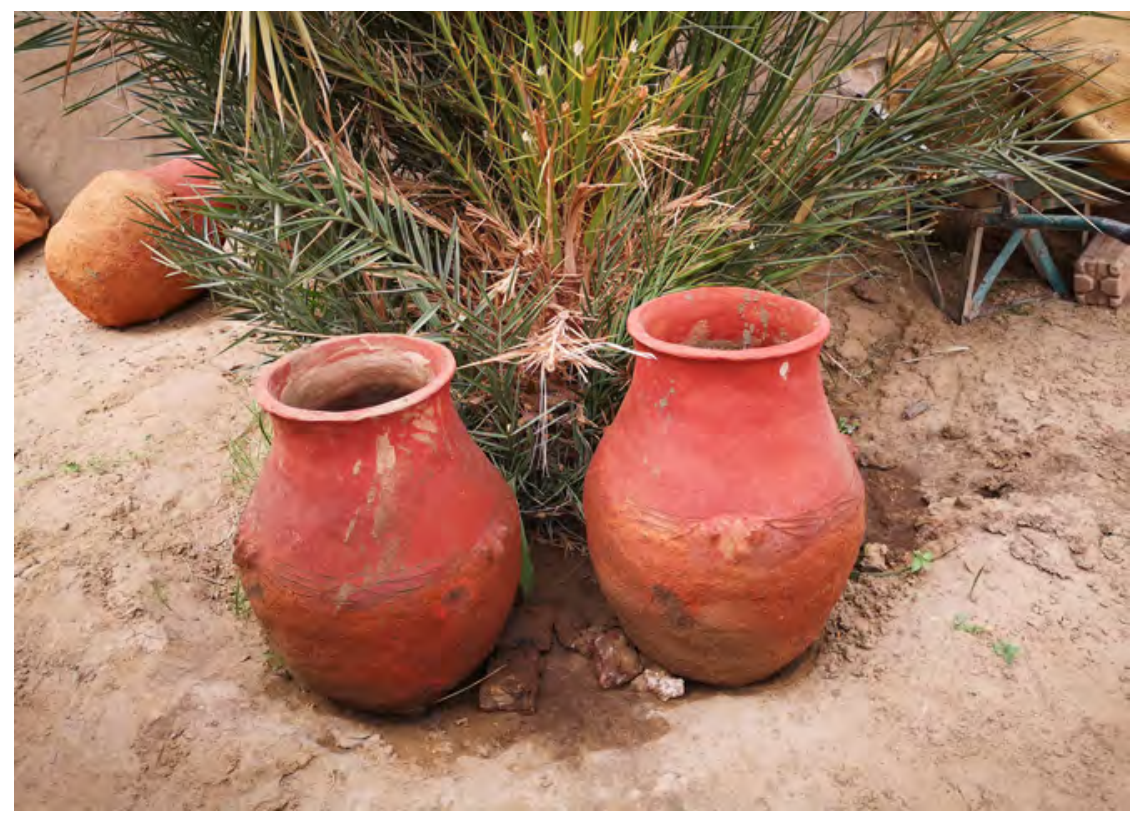

24. Azyār used for watering plants (Phot. P. Terendy). 


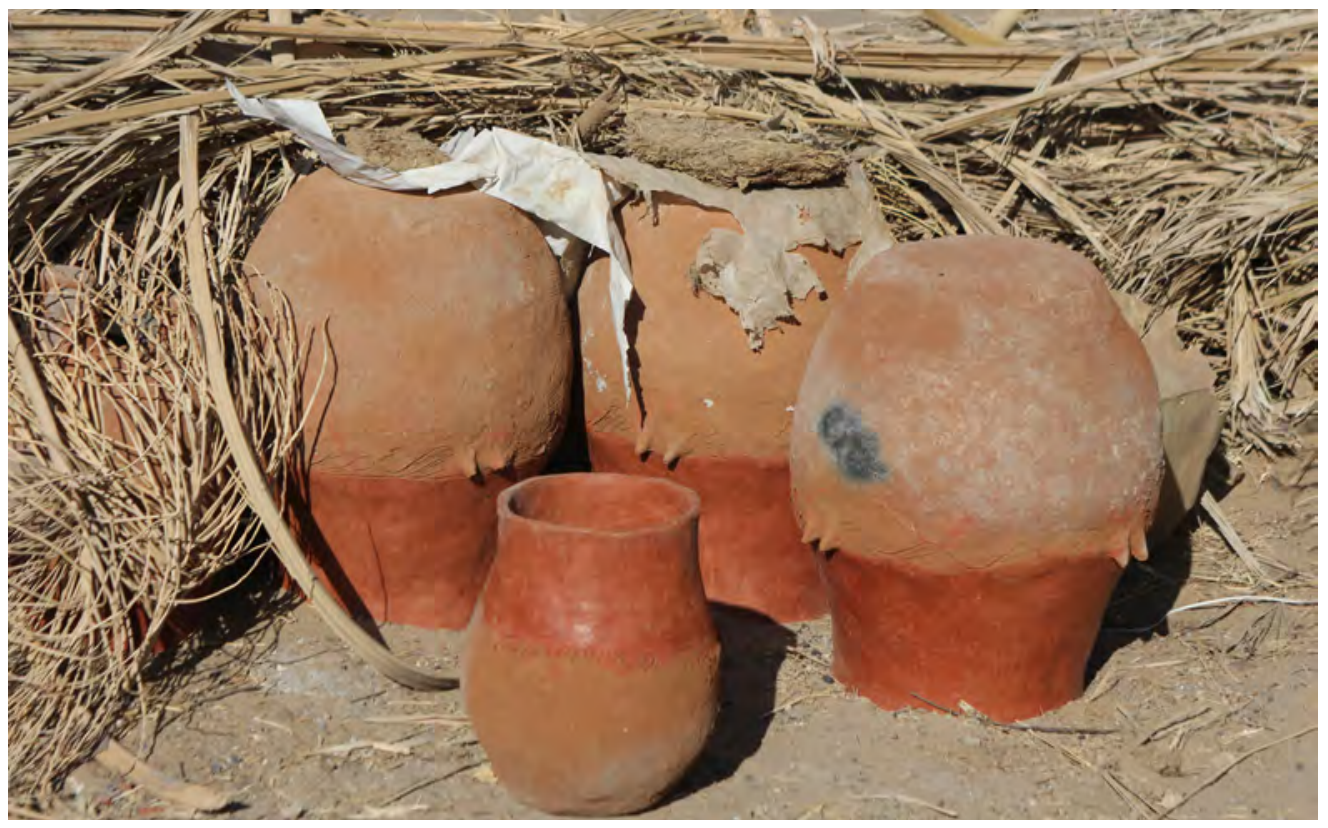

25. Large and medium-size azyār from Jabarūna (Phot. P. Terendy).

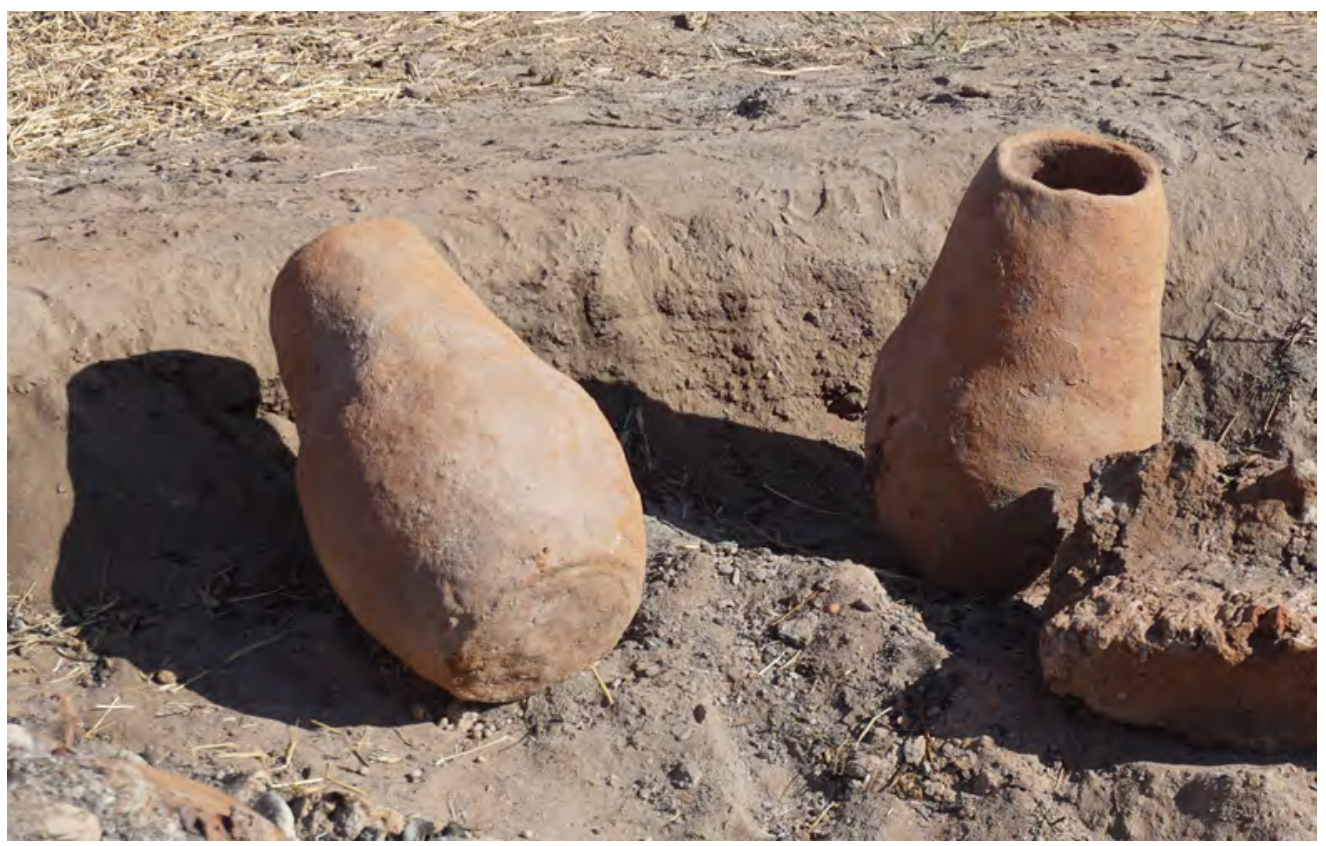

26. Rabbit traps made by the potters in Jabarūna (Phot. A. Cedro). 
Cylindrical pipes are used in the irrigation system as couplers that connect wooden troughs (Fig. 27).

Grain containers called qussība were made of sun-dried mud (Fig. 28). According to Abū l'Qāsim from Al-Qadār village, it took 25 days to make a good qussība. It was supposed to contain a sufficient amount of grain for one family for one year. It was provided with a lid atop and an orifice in the lower part plastered each time after the qussïba was used.

Wide-mouthed jars qulla are also used for the traditional dukhān (smoke bath). A jar is placed in a hole dug in the ground. Inside some pieces of a naturally scented talh wood are placed on the charcoal and ignited. Glowing wood gives smoke with a pleasant aroma. The hole in the earth with qulla below is covered with a round mat called taqarüba. On it sits an undressed woman, covered with a woollen rug (Ar. šamla) whose body is incensed with the smoke wafting from the qulla. While doing this she can rub her hair with karkār - a mixture of fat, sesame oil, cloves, orange peel and perfume. This practice gives a smoothness and pleasant fragrance to the skin and to the hair. After the dukhān is accomplished, the woman rubs into the skin dilka - a skin scrub made from millet or sorghum flour, ground cloves, scented oil and perfumes, smoked with sandal wood. Such treatment, performed in the female part of the house, can last from fifteen minutes to two hours, and even longer.

\section{SUMMARY}

Village pottery making is a traditional household industry in the Ad-Dabba Bend of the Nile. It is a seasonal, gendered, loosely organised activity that escapes categorisation according to technological criteria. Apart from a few exceptions, rural pottery production is in the hands of women, who learned the craft from their mothers. The Ad-Dabba workshop, run by Hausa migrants from a region where pottery making was the occupation of both men and women, makes a noble exception to the rule.

The information collected among the traditional potters still active in the Ad-Dabba Bend proves that household pottery making was neither dependent on urban centres for access to materials nor were the pots fired purposefully for sale in the regional markets.

The preferred spherical or subspherical pots produced mainly by women fit the definition of African wares coined in 1910 by Franz Stuhlman. ${ }^{19}$ A vast majority of the vessels we have the chance to see in various stage of shaping or firing have neither knobs nor any sort of handles.

The ceramic self-sufficiency and dense pattern of the village pottery production were caused by the very nature of ceramic products, which in general hates transport. The vast majority of the vessels produced today in the rural workshops are bigger form. Needless to say, transport made marketing of them difficult.

Nowadays when transport is easily available part of the local pottery production is to some extent sold out but the pots are fired occasionally and the amount is regulated by

19 Stuhlmann 1910: 26. 


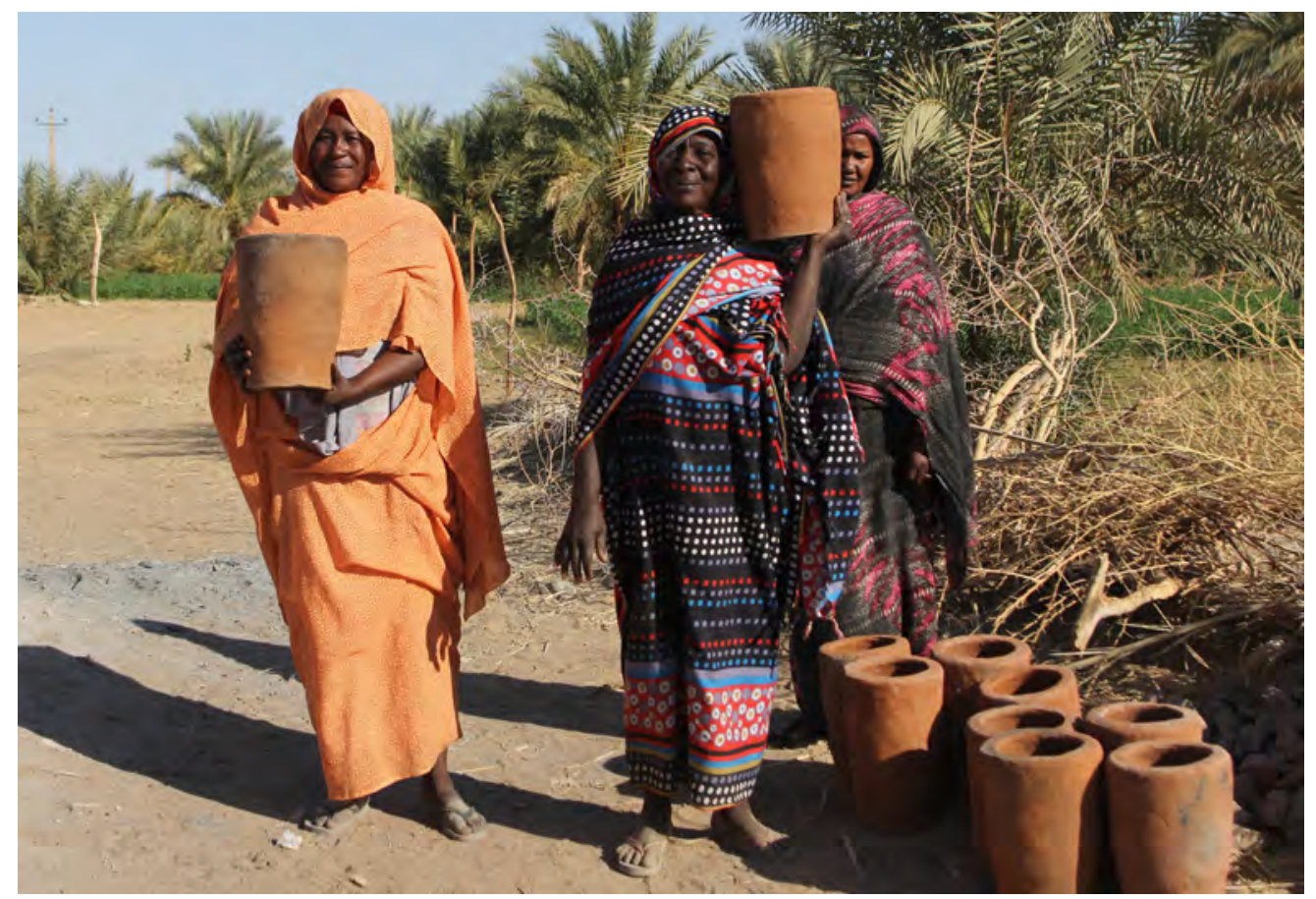

27. Potters from Jabarūna with ceramic pipes used in the irrigation system (Phot. P. Terendy).

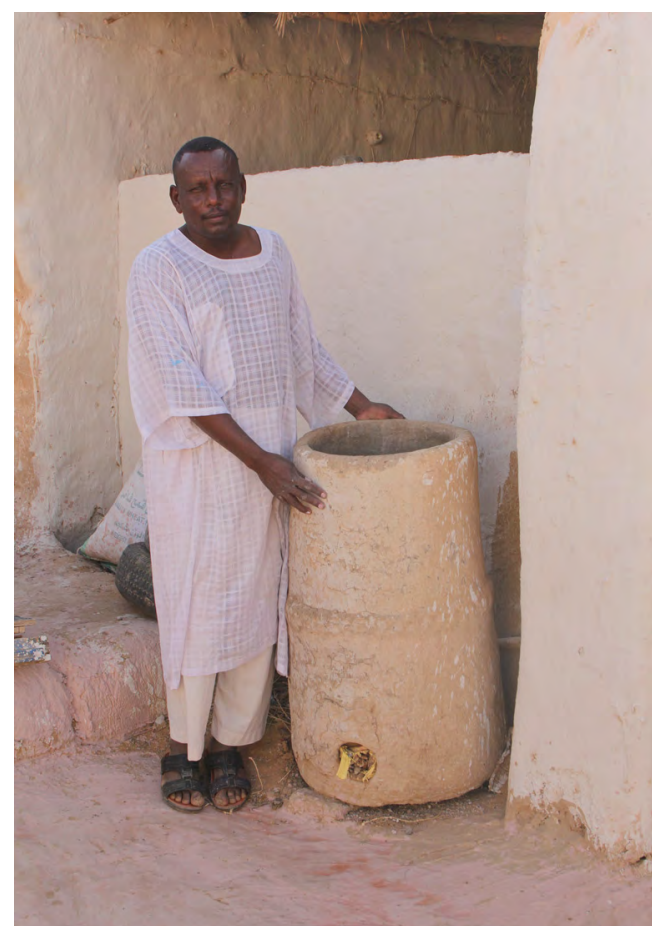

28. Grain container qussība (Phot. A. Terendy). 
demand. The forming and firing of vessels are usually made seasonally, mainly in summer when the work in the field is limited due to the heat, which incidentally greatly facilitated the firing operation and made the process more profitable because of quicker drying and less fuel consumption during firing.

In situ observations of the production procedure and ethnographic interviews suggest that pottery making for domestic use was more widespread in the past than it is at present. Then and now pots were fired in most primitive conditions in shallow pits located inside settlements, on the edge of cultivated land (al-arādi al-mazrū'a) near roads or even inside the settlements close to the potter's homestead. The choice of place was determined by the distance from the potter's place of residence and the availability of clay and fuel. It is difficult to talk about the concept of a ceramic workshop because most of the production process took place at home.

Village pottery manufacture is currently limited to ceramic products that cannot be replaced by a metal or plastic factory commodity available on the local market. However, in the past women potters of Ad-Dabba Bend, as elsewhere in sub-Saharan Africa, were the main users of the vessels they manufactured. Today, they produce mostly vessels for storing and cooling water, but earlier they also made cooking pots, birām (sing. burma), vessels for brewing and storage of beer (marissa).

The manufacturing of the pots is carried out by men and women. Men are responsible for making pipes, saqiyya-pots (qawādīs), ceramic novelties, jabanāt and, generally, more complicated shapes. Earlier the male potters monopolised the production of ceramics turned on wheel.

The pattern of village pottery-making in the Ad-Dabba Bend is similar to that still observed in Upper Egypt in the 1920s. Winifred S. Blackman's sentence from her The Fellahin of Upper Egypt characterised both Middle Nile and Upper Egypt pottery making as follows: When no wheel is employed the potters may be men or women, but the wheel is used only by men. ${ }^{20}$

\section{Acknowledgements}

The paper is a result of the project sponsored by the National Science Centre, Poland titled 'Angels and Locusts. Everyday life in Banganarti, the pilgrimage centre on the Middle Nile between the 6th and 16th century' (no. 2016/21/B/HS3/03724). The project is executed in the Institute of Mediterranean and Oriental Cultures, Polish Academy of Sciences. We would like to thank the male and female potters for a time they did not spare us while initiating us into the secrets of their profession. Despite their openness and kindness it was difficult to obtain consistent data on workshops that had already ended their activities. Information on them provided in many cases by elderly people was often contradictory. We would like to especially thank the Arabist Andrzej Leligdowicz, who tried to interview everyone who might have known something about the bygone and modern production of ceramics in the region, for devoting so much time and energy to find the truth, which in

20 Blackman 2000: 135. 
many cases proved unattainable. This paper could not have been created without the rich set of information that he collected.

\section{References}

Arkell, A.J. 1939: Darfur Pottery, SNRec 22, 79-88

Balfet, H. 1965: Ethnographical observations in North Africa and archaeological interpretation: the pottery of the Maghreb, [in:] Matson, F.R. (Ed.) Ceramics and Man, Viking Fund Publications in Anthropology 41, New York, 161-177

Bentley, O., Crowfoot, J.W. 1924: Nuba Pots in the Gordon College, SNRec 7/2, 18-28

Berns, M.C. 1993: Art, history, and gender: women and clay in West Africa, AAR 11, 129-148

Blackman, W.S. 2000: The fellahin of Upper Egypt, Cairo

Bradley, H. 1989: Men’s Work, Women’s Work: a Sociological History of the Sexual Division of Labour in Employment, Feminist perspectives, Minneapolis

Crowfoot, J.W. 1925: Further Notes on Pottery, SNRec 8, 125-136

Crowfoot, J.W. 1933: Pot Making in Dongola Province, Sudan, Man 33, 11-12

D’Ercole, G., Garcea, E.A.A., Eramo, G., Muntoni, I.M. 2017: Variability and continuity of ceramic manufacturing of prehistoric pottery from Upper Nubia, Sudan: An ethnographic comparison, Journal of Archaeological Sciences: Reports 16, 553-563

Dirar, H.A. 2015: The Indigenous Fermented Foods of the Sudan, Wallingford

Garcea, E.A.A. 2004: Two different pottery productions in Northern Sudan, SudNub 8, 95-102

Gosselain, O.P. 2008: Ceramics in Africa, [in:] Selin, H. (Ed.), Encyclopedia of the History of Science, Technology, and Medicine in Non-Western Cultures, Dordrecht, 1074-1090

Gosselain, O.P. 2015: Roads, Markets, Migrants. The Historical Trajectory of a Male Hausa Pottery Tradition in southern Niger, [in:] Gauß, W., Klebinder-Gauß, G., Rüden, C. von (Eds), The Distribution of Technological Knowledge in the Production of Ancient Mediterranean Pottery, Vienna, 277-296

Haaland, R. 1976: Ethnographical Observations of Pottery-Making in Darfur, Western Sudan, with some Reflections on Archaeological Interpretation, [in:] Kristiansen, K., Pauludan-Muller, C. (Eds), New Directions in Scandinavian Archaeology, Studies in Scandinavian Prehistory and Early History 1, Copenhagen, 47-61

Kleppe, E.J. 1982: The Debbas on the White Nile, Southern Sudan, [in:] Mack, J., Robertshaw, P. (Eds), Culture History in the Southern Sudan: Archaeology, Linguistics, and Ethnohistory, Memoir of the British Institute in Eastern Africa 8, Nairobi, 59-70

Leeuw, S.E. van der 1977: Towards a Study of the Economics of Pottery Making, [in:] Beek, B.L. van, Brandt, R.W., Groenman-Van Waateringe, W. (Eds), Ex Horreo, Amsterdam, 68-76

Lyons, D., Freeman, A. 2009: I'm not evil: Materialising identities of marginalised potters in Tigray Region, Ethiopia, Azania 44/1, 75-93 
MacMichael, H.A. 1922: Pottery Making on the Blue Nile, SNRec 5/1, 33-38

Musa Mohammed, I. 1986: The archaeology of Central Darfur (Sudan) in the 1st millennium A.D., BAR-IS 285, Oxford

Nabil Ali 2010: Regionalism and Social Landscape as Inferred from an Ethnoarchaeological Study of Pottery Production in Jordan, Journal of Anthropological Research 66/3, 351-373

Stössel, A. 1984: Afrikanische Keramik traditionelle Handwerkskunst südlich der Sahara, München

Stuhlmann, F. 1910: Handwerk und Industrie in Ostafrika. Kulturgeschichtliche Betrachtungen, nebst einem Anhang: Die Gewinnung des Eisens bei den Nyamwezi by Stern, R., Abhandlungen des Hamburgischen Kolonialinstituts, series B, Völkerkunde, Kulturgeschichte und Sprachen I, Hamburg 


\section{ÉTUDES et TRAVAUX XXXII / 2019}

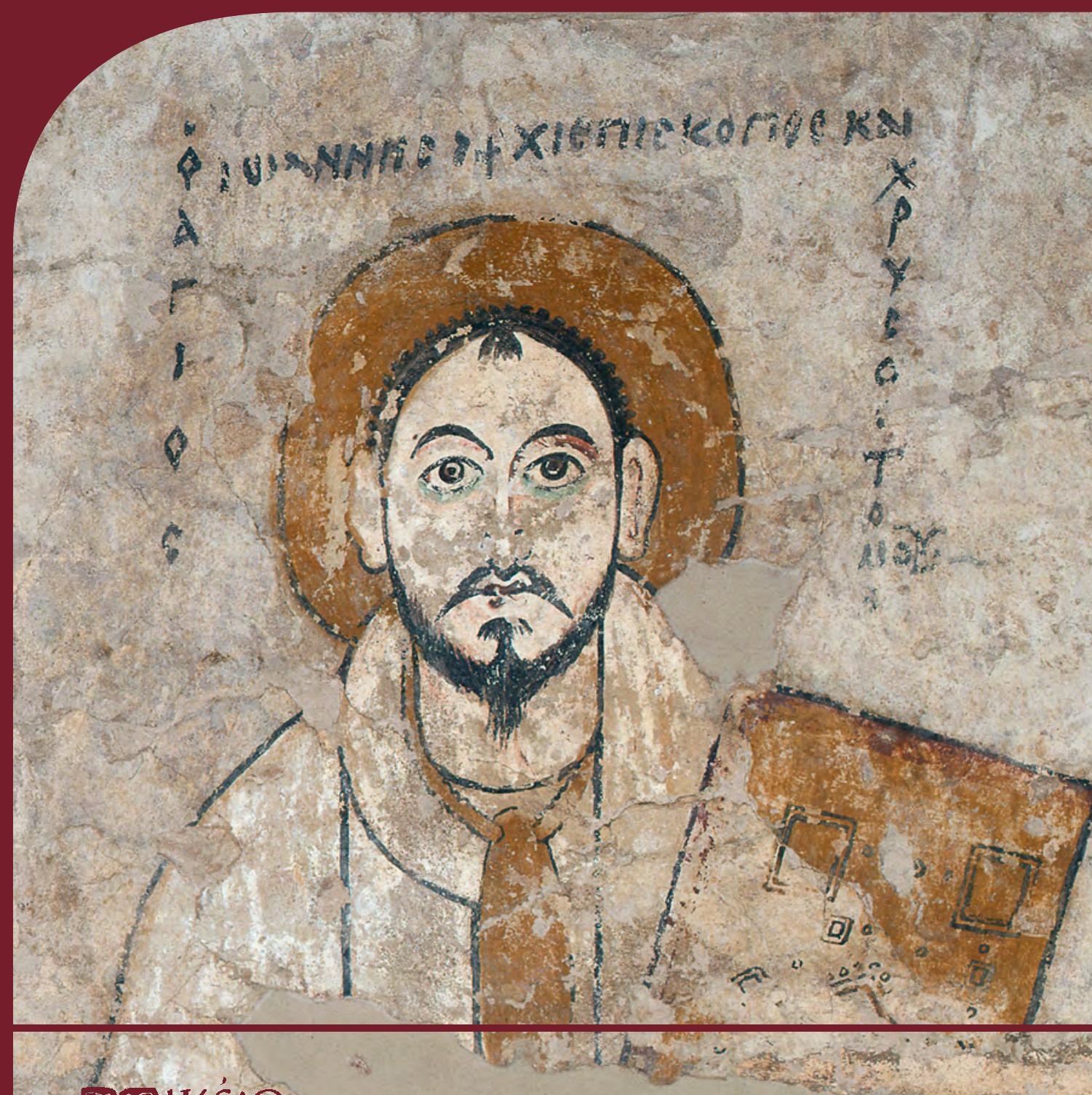

BOMIKSiO Institut des Cultures Méditerranéennes et Orientales ED2A PAN de l'Acácémie Polonaise des Sciences 


\title{
COMITÉ DE RÉDACTION SCIENTIFIQUE
}

Maciej Makowski - rédacteur en chef Jadwiga Iwaszczuk - rédacteur

Maciej G. Witkowski - rédacteur

Agnieszka Ryś - sécretaire de la rédaction

Bogdan Żurawski - rédacteur thématique du volume

CONSEIL SCIENTIFIQUE DU JOURNAL

M. Kobusiewicz (IAE PAN, Warszawa), E. Laskowska-Kusztal (IMOC PAS, Warszawa),

D. Michaelides (University of Cyprus, Nicosia),

J.Ch. Moretti (IRAA-MOM, Université de Lyon 2/CNRS),

D. Raue (Ägyptisches Museum der Universität Leipzig), P. Reynolds (ICREA, España),

D. Welsby (British Museum, London)

\section{COMITÉ SCIENTIFIQUE DE LECTURE}

D.E. Arnold (Wheaton College/The Field Museum, Chicago), H.D. Baker (University of Toronto),

P. Ballet (ArScAn-ESPRI, Université Paris Nanterre), Ch. Barber (Princeton University),

N. Beaux-Grimal (IFAO, Caire/Collège de France, Paris), A. Boud'hors (CNRS, IRHT, Paris),

J. Budka (Ludwig-Maximilians-Universität München), R. David (SFDAS),

A. Delattre (CPEG, Bruxelles), A. Dodson (University of Bristol),

E. Fogliadini (Facoltà Teologica dell'Italia Settentrionale, Milan),

V. Francigny (CNRS/CRES, Paris), L. Gabolde (CNRS), C. Gobeil (Egypt Exploration Society, London),

N. Hamdi (UCL, Louvain), J. den Heijer (CIOL/INCAL, Louvain-la-Neuve),

S. Ikram (American University in Cairo), Ch. Leitz (Universität Tübingen), S. Ortisi (Universität München),

E. Rova (Università Ca' Foscari Venezia), G. Ruffini (Fairfield University),

A. Sasson (San Diego Natural History Museum), H. Satzinger (Universität Wien),

S.M. Schellinger (The Ohio State University, Columbus), G. Schreiber (Eötvös Loránd University, Budapest),

E. Teeter (University of Chicago), S. Torallas-Tovar (University of Chicago),

Y. Tristant (Macquarie University, Sydney), V. Vaelske (independent researcher),

H. Vymazalová (Charles University, Prague), P. Weschenfelder (Universität Wien),

B. Williams (University of Chicago/PCMA UW, Warszawa),

K. Winther-Jacobsen (The Danish Institute at Athens), E. Zacharopoulou (University of Johannesburg),

P. Grotowski (UPJPII, Kraków), E. Papuci-Władyka, J. Śliwa (IA JU, Kraków), A. Ćwiek (IA AMU, Poznań),

K.O. Kuraszkiewicz, M. Pinker (FOS UW, Warszawa), Ł. Niesiołowski-Spanò (IH UW, Warszawa),

M. Gawlikowski, Mahmoud El-Tayeb (PCMA UW, Warszawa), S. Rzepka (IA UW, Warszawa)

\author{
RÉDACTION TECHNIQUE \\ Monika Wesołowska
}

REVUE DES TEXTES ANGLAIS

Jo Harper 
ÉTUDES et TRAVAUX

XXXII 
INSTYTUT KULTUR ŚRÓDZIEMNOMORSKICH I ORIENTALNYCH POLSKIEJ AKADEMII NAUK

\title{
STUDIA i PRACE
}

\author{
XXXII
}

gू IKŚiO

ESAN

WARSZAWA

2019 
INSTITUT DES CULTURES MÉDITERRANÉENNES ET ORIENTALES DE L’ACADÉMIE POLONAISE DES SCIENCES

\section{ÉTUDES et TRAVAUX}

XXXII

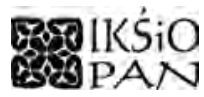

VARSOVIE

2019 
Publication scientifique financée dans le cadre du programme du Ministre de la Science et de l’Éducation Supérieure

« Programme National de Développement de l’Humanistique » pour les années 2016-2021 (projet no $3 b H 150099$ 83)

\title{
TI NARODOWY PROGRAM ROZWOJU HUMANISTYKI
}

\author{
Copyright $(\mathbb{C}$ \\ Instytut Kultur Śródziemnomorskich i Orientalnych PAN \\ et les Auteurs \\ Warszawa 2019
}

\begin{abstract}
ISSN 2084-6762
(avant 2011 : 0079-3566)

e-ISSN 2449-9579

Version première en papier, imprimée en Pologne - 150 copies

Version électronique accessible sur

http://www.etudesettravaux.iksiopan.pl
\end{abstract}

Édition: Polskie Towarzystwo Historyczne et Wydawnictwo Neriton, Warszawa

Conception générale de couverture : J. Iwaszczuk

Photo de couverture : P. Ligier ; courtoisie du Musée National de Varsovie

(Saint Jean Chrysostome, peinture, cathédrale de Faras). 


\section{Table des matières}

Editorial: Quid novi ex Nubia (par Bogdan Żurawski) ............................................... 7

Bibliography of Professor Stefan Jakobielski ................................................................ 13

Aneta Cedro, Bogdan Żurawski

Living with the Past in Modern Sudanese Village. Traditional Pottery Production

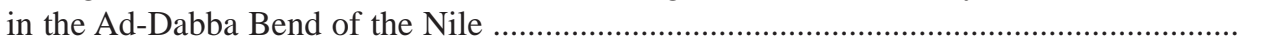

DAVID N. EDWARDS

A Possible Monastery and the 'Upper Maqs’ at Ukma-Akasha West? ............................ 53

Vincent W.J. van GeRven OeI

An Old Nubian Curse from the Faras Cathedral ........................................................ 81

Vincent W.J. van Gerven Oei, Adam Łajtar

Two Old Nubian Inscriptions from Akasha West ........................................................ 89

Vincent W.J. van Gerven Oei, Alexandros Tsakos

Rubrication Patterns in Two Old Nubian Manuscripts from Serra East .......................... 99

KAREL C. INNEMÉE

A Man in a Vessel, Once More .................................................................................. 111

KAREL C. INNEMÉE, Dobrochna ZielińSKA

Faces of Evil in Nubian Wall-Painting - An Overview ................................................ 121

ADAM ŁAJTAR

Epitaph of Merki Found in Hambukol ....................................................................... 145

MAGDALENA ŁAPTAŚ

Attributes, Vestments, Context and Inscription in the Identification of Nubian

Paintings: Proposing the 'Multi-Layer' Image Recognition Method ............................... 161

Grzegorz Ochala

Nubica Onomastica Miscellanea I: Notes on and Corrections to Personal Names

Found in Inscriptions from Faras 


\section{Robin SEIGNOBOS}

L'influence du Kitāb ahbār al-Nūba d'Ibn Sulaym al-Uswānī sur l'Histoire des églises et monastères d'Égypte d'Abū al-Makārim

JACQUES VAN DER VLIET

Exit Bishop Tamer - the Sequel. A New Edition of the Epitaph of Papsine alias Doulista (DBMNT 78) 